Volume 7

Number 4 Unsolicited Issue

Article 2

$5-12-2021$

\title{
Knick and the Elephant in the Courtroom: Who Cares Least About Property Rights?
}

\section{R. S. Radford}

The Radford Center for Law, History \& Economics, rsradford@gmail.com

Follow this and additional works at: https://scholarship.law.tamu.edu/journal-of-property-law

Part of the Property Law and Real Estate Commons

\section{Recommended Citation}

R. S. Radford, Knick and the Elephant in the Courtroom: Who Cares Least About Property Rights?, 7 Tex. A\&M J. Prop. L. 577 (2021).

Available at: https://doi.org/10.37419/JPL.V7.14.2

This Student Article is brought to you for free and open access by Texas A\&M Law Scholarship. It has been accepted for inclusion in Texas A\&M Journal of Property Law by an authorized editor of Texas A\&M Law Scholarship. For more information, please contact aretteen@law.tamu.edu. 


\title{
KNICK AND THE ELEPHANT IN THE COURTROOM: WHO CARES Least About Property Rights?
}

\author{
R. S. Radford*
}

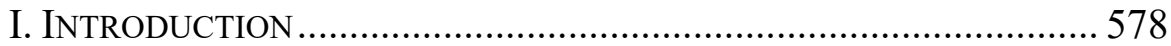

II. THE THIRTY-YEAR MISTAKE ……………………………………..... 580

A. Williamson County - Laying a Minefield Without a Map 580

B. Ripeness or Rot? Williamson County Evolved in Ways Both

Unforeseen and Inevitable .......................................... 587

C. Knick Finally Drives a Stake Through Williamson County 591

III. The Elephant IN THE COURTROOM-WiLl Federal CourTs

RISE TO THE CHALLENGE?.................................................55

A. Both Supporters and Critics of Knick Assume the Decision

Will Lead to More Successful Takings Lawsuits ........... 595

B. The Sorry History of Federal-Court Enforcement of the

Takings Clause Offers Little Support for That View .... 599

1. For Decades, Federal Judges Have Freely Expressed Their Distaste for Adjudicating the Constitutionality of Land Use Restrictions................................................ 599

2. Abstention Offered an Inviting Way for Federal Courts to Avoid Adjudicating Takings Cases 602

3. The Mousetrap at the End of the Maze: Few Takings Claims That Have Actually Been Adjudicated in Federal Court Have Prevailed. 608

4. Guggenheim v. Goleta Illustrates the Lengths to Which Federal Courts Have Gone to Avoid Imposing Takings Liability on Local Governments . 612

5. Epilogue: The Ninth Circuit Becomes Both Judge and Jury in Takings Cases 616

IV. CONCLUSION: A NEW DAY OR . . . ?........................................ 620

DOI: https://doi.org/10.37419/JPL.V7.I4.2

${ }^{*}$ Director, The Radford Center for Law, History, and Economics. The author filed a brief amicus curiae in support of the petitioners in Knick v. Township of Scott. Helpful comments on an earlier draft of this Article were provided by Luke Wake and Larry Salzman. 


\section{INTRODUCTION}

"When there's an elephant in the room, introduce him."

In Knick v. Township of Scott, ${ }^{2}$ the Supreme Court corrected one of the most egregious and inexplicable blunders of its 230 -year history. For more than three decades, plaintiffs who alleged a violation of the Takings Clause by state or local governments were barred from suing for compensation in federal court. ${ }^{3}$ The source of this prohibition was Justice Blackmun's 1985 opinion in Williamson County Regional Planning Commission v. Hamilton Bank of Johnson City ${ }^{4}$ - a decision that most scholars and practitioners believe rested on a fundamental misunderstanding of both constitutional text and legal procedure. ${ }^{5}$

Williamson County was not only doctrinally indefensible, but the Court that handed down the decision apparently failed to grasp its procedural implications. Although the opinion was rife with language suggesting that a Fifth Amendment takings claim could be "ripened" for federal litigation by first seeking just compensation in state court, complying with that requirement would in fact bar the plaintiff from pursuing the claim further in any forum, state or federal. ${ }^{6}$ It took the Court twenty years to acknowledge this self-evident, procedural catch22 and over a decade to remedy it by overruling Williamson County. ${ }^{7}$

1. AZ QUOTES, https://www.azquotes.com/quote/364227 (last visited Feb. 26, 2021) [https://perma.cc/7EYP-ZMX4] (citing Carnegie Mellon University, Randy Pausch Last Lecture: Achieving Your Childhood Dreams, YouTUBE (Dec. 20, 2007), https://www.youtube.com/watch?v=ji5_MqicxSo [https://perma.cc/QAW9FT93]).

2. 139 S. Ct. 2162, 2162 (2019).

3. The Takings Clause of the Fifth Amendment to the United States Constitution provides, "nor shall private property be taken for public use, without just compensation." U.S. CONST. amend. V. This provision was incorporated into the Due Process Clause of the Fourteenth Amendment for application to state and local governments by Chicago, Burlington \& Quincy Railroad Co. v. City of Chicago, 166 U.S. 226 (1897).

4. See Williamson Cty. Reg'l Planning Comm'n v. Hamilton Bank of Johnson City, 473 U.S. 172, 172 (1985).

5. See infra note 53.

6. See Williamson County, 473 U.S. at 194 (it was "premature" to file takings claim in federal court before seeking compensation in state court); id. at 197 (federalcourt takings claim is "not yet ripe" until plaintiff has sued for compensation in state court).

7. See San Remo Hotel v. City and County of San Francisco, 545 U.S. 323, 325 (2005) (acknowledging that complying with Williamson County could not "ripen" a takings claim for federal adjudication, as the decision stated); See Knick v. Twp. of Scott, 139 S. Ct. 2162, 2167 (overruling Williamson County). 
Throughout the thirty-four-year history of Williamson County, one fact was taken for granted. Never directly mentioned but always looming in the background of two rounds of oral argument before the Supreme Court in Knick was the premise that relegating takings claims to state court made it less likely that property owners would prevail on those claims than if they could be filed in federal court in the first instance. This Article examines that premise and finds little support for it in the historical record.

Part I of this Article discusses Williamson County and highlights the logical, doctrinal, and procedural confusion associated with the opinion, both in its conception and as the consequences of the ruling were revealed over time. ${ }^{8}$ It concludes with a brief review of the Knick decision, which finally laid Williamson County to rest. ${ }^{9}$ Part II turns to the "elephant in the courtroom"- the generally unspoken assumption that reopening the federal courthouse doors to takings claims will significantly increase the number of claims that result in awards of compensation. ${ }^{10}$ Part II also points out that, both before Williamson County and after, federal courts have expressed a strong distaste, if not outright contempt, for becoming involved in land-use disputes. ${ }^{11} \mathrm{~A}$ review of the pre-Williamson County practice of invoking abstention to clear the federal judiciary's calendar of takings cases ${ }^{12}$ is followed by an examination of the extremely low success rate of takings cases that have managed to avoid both Williamson County and abstention and adjudicated on their merits in federal court. ${ }^{13}$ A case study of Guggenheim v. City of Goleta ${ }^{14}$ exemplifies the Ninth Circuit's policy of dismissing takings challenges to regulations that predate a plaintiff's acquisition of title - in direct contravention of the Supreme Court's ruling in Palazzolo v. Rhode Island. ${ }^{15}$ Finally, the Ninth Circuit's most recent foray into takings law, Bridge Aina Le'a v. State of Hawaii Land-Use Commission, ${ }^{16}$ raises the question of whether the Circuit is flouting the Seventh Amendment's Re-examination Clause

8. See infra notes 19-71 and accompanying text.

9. See infra notes 72-92 and accompanying text.

10. See infra notes 93-117 and accompanying text.

11. See infra notes 118-29 and accompanying text.

12. See infra notes $130-65$ and accompanying text.

13. See infra notes 166-193 and accompanying text.

14. Guggenheim v. City of Goleta, 582 F.3d 996, 1037 (9th Cir. 2009) [hereinafter Guggenheim I], vacated on reh'g en banc, Guggenheim v. City of Goleta, 638 F.3d 1111, 1111 (9th Cir. 2010) [hereinafter Guggenheim II].

15. 533 U.S. 606, 629 (2001); see infra notes 194-217 and accompanying text

16. 950 F.3d 610 (9th Cir. 2020), petition for cert. filed, (U.S. July 22, 2020) (No. 20-54). 
in its eagerness to set aside jury verdicts of takings liability. ${ }^{17}$ Part IV concludes this Article by reminding the reader that Knick has essentially returned federal takings jurisprudence to where it stood in 1984-before Williamson County cut off its development by diverting most takings cases to state court. ${ }^{18}$ How the federal judiciary responds to the Knick challenge will set the parameters of takings law for the twenty-first century.

\section{THE THIRTY-YEAR MISTAKE}

\section{A. Williamson County-Laying a Minefield Without a Map}

The Williamson County opinion was unique in many respects. The Court did not decide the question presented for review. The question the Court decided had not been briefed or argued below; the Court was unable to find a coherent rationale for its holding, and no one had thought through the readily foreseeable consequences of the decision.

The case arose after the denial of permits by the Williamson County Regional Planning Commission that were required to complete the development of a residential subdivision. ${ }^{19}$ Hamilton Bank, which had acquired title to the project through foreclosure, sued the agency in federal court for a regulatory taking of the undeveloped property and was awarded compensation by a jury. ${ }^{20}$ The trial judge overturned the damages award, but the Sixth Circuit Court of Appeals reinstated the award, holding that just compensation was required for even a temporary denial of all beneficial use of property. ${ }^{21}$ The Supreme Court granted certiorari to address the question of whether federal, state, and local governments must pay money damages to a landowner whose property was allegedly "taken" temporarily by the application of government regulations. ${ }^{22}$ This question, however, was not addressed. ${ }^{23}$ Instead, the Court created a novel "ripeness" doctrine out

17. See infra notes $218-47$ and accompanying text.

18. See infra notes $248-51$ and accompanying text.

19. Williamson Cty. Reg'l Planning Comm'n v. Hamilton Bank of Johnson City, 473 U.S. 172, 180 (1985).

20. Id. at 175 .

21. Id.; Hamilton Bank of Johnson City v. Williamson Cnty. Reg'l Planning Comm'n, 729 F.2d 402, 409 (6th Cir. 1984), rev'd, 473 U.S. 172 (1985).

22. Williamson Cty., 473 U.S. at 185.

23. Id. ("[W]e find that the question is not properly presented, and must be left for another day.") That day came two years later, in First English Evangelical Lutheran Church of Glendale v. Cty. of Los Angeles, 482 U.S. 304, 321 (1987). 
of whole cloth-under which the federal courts could not hear Hamilton Bank's Fifth Amendment takings claim at all.

As a prelude, the majority found that the claim was not ripe for adjudication because the developer had "not yet obtained a final decision regarding the application of the zoning ordinance and subdivision regulations to its property." 24 This first prong of Williamson County's new ripeness doctrine, the "finality" requirement, unleashed a torrent of chaos and unpredictability into takings law that persists to this day despite three subsequent Supreme Court opinions attempting to clarify exactly what constitutes "finality" on a case-by-case basis. ${ }^{25}$ The opinion's inherent obscurity as to when a land-use decision may be sufficiently final to create a ripe takings claim has been further clouded by the courts, which have sometimes seemed eager to create new procedural stumbling blocks to avoid adjudicating such claims on the merits. ${ }^{26}$ An especially egregious example was a ruling by the Ninth Circuit Court of Appeals that an agency's outright prohibition of any economically beneficial use of property was not "final" until the aggrieved property owners tried to amend the regional land-use plan to accommodate development. ${ }^{27}$

Nevertheless, all the difficulties and uncertainties that were generated by Williamson County's finality requirement paled in comparison to what came next. Having seemingly concluded his analysis of why Hamilton Bank's takings claim was not ripe, Justice Blackmun continued by stating, "A second reason the taking claim is

24. Williamson Cty., 473 U.S. at 186. This was a puzzling statement, given that Hamilton Bank had received a determination from the County Board of Zoning Appeals that it was entitled to proceed with its development as originally planned. However, "[the Regional] Planning Commission [had] refused to acknowledge that decision. The County Attorney advised Hamilton Bank that any further resort to the Board of Zoning Appeals would be futile, as the Planning Commission would ignore its determination." Michael M. Berger, Anarchy Reigns Supreme, 29 WASH. U. J. URB. \& CONTEMP. L. 39, 53 (1985)..

25. See MacDonald, Sommer \& Frates v. Yolo Cty., 477 U.S. 340, 351-53 (1986) (holding that a property owner who is denied approval of development allowed under existing regulations must seek approval for less intensive uses); Suitum v. Tahoe Reg'l Planning Agency, 520 U.S. 725, 739 (1997) (holding that an agency's decision is final when it has no further discretion to approve permit); City of Monterey v. Del Monte Dunes at Monterey, 526 U.S. 687, 698-99 (1999) (holding that the government may not impose repetitive or unfair procedures in order to avoid reaching a final decision).

26. See generally, Gregory Overstreet, The Ripeness Doctrine of the Taking Clause: A Survey of Decisions Showing Just How Far Federal Courts Will Go to Avoid Adjudicating Land Use Cases, 10 J. LAND USE \& ENVTL. L. 91, 124 (1994).

27. Tahoe-Sierra Pres. Council v. Tahoe Reg'l Planning Agency, 911 F.2d 1331, 1336 (9th Cir. 1990). 
not yet ripe is that respondent did not seek compensation through the procedures the state provided for doing so." 28

This was a startling proposition that had never before been suggested by any court and had not been considered by the Sixth Circuit or the district court proceedings in Williamson County. ${ }^{29}$ The sole basis for this novel, procedural rule was an amicus brief the Solicitor General filed in the Supreme Court, which posed the question:

Whether, under this Court's decision in Parratt $v$. Taylor... respondents claim that its property was taken without just compensation in violation of the Fifth and Fourteenth Amendments should have been dismissed because respondent did not pursue procedures under state law to obtain compensation or show that those procedures are inadequate. ${ }^{30}$

In Parratt, an inmate at a Nebraska prison ordered hobby materials through the mail, which were delivered to the prison but disappeared before reaching him. ${ }^{31}$ The inmate sued the warden, alleging that the loss of the materials amounted to an unconstitutional deprivation of

28. Williamson Cty., 473 U.S. at 194. Although Justice Blackmun's opinion requires litigants to avail themselves of any "procedures" a state might make available for obtaining compensation, this has been universally interpreted narrowly as a requirement to file an inverse condemnation claim or its equivalent under state law, in state court. See, e.g., Knick v. Twp. of Scott, Pa., 139 S. Ct. 2162, 2169 (characterizing the holding in Williamson County as requiring property owners to "seek just compensation under state law in state court before bringing a federal takings claim"); San Remo Hotel v. City of San Francisco, 545 U.S. 323, 331 ("Because petitioners had failed to pursue an inverse condemnation action in state court, they had not yet been denied just compensation as contemplated by Williamson County.").

29. See, e.g., Joshua D. Hawley, The Beginning of the End? Horne v. Department of Agriculture and the Future of Williamson County, 2013 CATO SUP. CT. REV. 245, 246 ("[I]n no case before Williamson County did any federal or state court ever suggest that it lacked jurisdiction to hear a takings claim, or that the claim was somehow premature, merely because the claimant had not yet attempted to obtain compensation from the government.").

30. Brief for the U.S. as Amicus Curiae Supporting Petitioners, Williamson Cty. Reg'l Planning Comm'n v. Hamilton Bank, 473 U.S. 172, 172 (1985) (No. 84-4), 1984 WL $565763 * 1$. Such a rule had previously been suggested (albeit without analogizing to Parratt) in a law review article by William Ryckman, but there is no evidence that either the Solicitor General or the Williamson County Court were familiar with it. See William E. Ryckman, Jr., Land Use Litigation, Federal Jurisdiction and the Abstention Doctrines, 69 CALIF. L. REV. 377, 395 n.104 (1981).

31. Parratt v. Taylor, 451 U.S. 527, 529 (1981). 
property without due process of law. ${ }^{32}$ The Supreme Court ruled that the inmate's due process rights were not violated because the loss of his materials resulted from the "random and unauthorized" acts of the prison's employees, rather than from any established procedure. ${ }^{33}$ Because Nebraska tort law provided a means to recover the value of the lost property, there was no due process violation. ${ }^{34}$

It was immediately evident that the formal denial of development permits in Williamson County had nothing to do with due process, nor could it plausibly have been described as a random and unauthorized act. Hamilton Bank's opposition brief highlighted the Solicitor General's faulty analogy between takings cases and the issue posed by Parratt. The brief noted that because regulatory takings effected by land-use agencies usually occur only after lengthy formal proceedings, Parratt was clearly inapposite, and there was no logical bar to immediately seek a remedy for the constitutional violation in federal court. ${ }^{35}$ At one point, Justice Blackmun's majority opinion seemed to recognize the inapplicability of Parratt, noting that the Parratt rule "does not extend to situations . . . in which the deprivation of property is effected pursuant to an established state policy or procedure, and the state could provide pre-deprivation process." ${ }^{36}$ Yet even after this concession, the opinion insisted that "Parratt's reasoning applies here by analogy."37

The only other precedential basis that Williamson County could claim for the new "state procedures" requirement was by analogy to Ruckelshaus v. Monsanto Co.,${ }^{38}$ which Justice Blackmun cited for the proposition that "takings claims against the federal government are premature until the property owner has availed itself of the process provided by the Tucker Act." 39 But this reflected an even deeper misunderstanding of takings law than the reliance on Parratt. In Monsanto, a titular chemical company sought to enjoin, under the Takings Clause, provisions of a federal law that would result in the

32. Id.

33. Id. at 541.

34. Id. at 543-44.

35. Brief for Respondent Hamilton Bank of Johnson City, Williamson Cty. Reg'l Planning Comm'n v. Hamilton Bank of Johnson City, 473 U.S. 172 (1985) (No. 844), 1984 WL 565756, at*39.

36. Williamson Cty. Reg'1 Planning Comm'n v. Hamilton Bank of Johnson City, 473 U.S. 172, 196 n. 14 (1985).

37. $I d$.

38. 467 U.S. 986,986 (1984).

39. Williamson Cty., 473 U.S. at 195 (citing Monsanto, 467 U.S. at 1016-20). 
disclosure of certain trade secrets. ${ }^{40}$ The Court found that the data in question qualified as private property, protected by the Fifth Amendment. ${ }^{41}$ However, the equitable relief that Monsanto sought was not available to enjoin a taking by the federal government; Monsanto's exclusive remedy was to file suit for just compensation in the Court of Federal Claims, pursuant to 28 U.S.C. § 1491 (the "Tucker Act"). ${ }^{42}$ Thus, Monsanto's claim for equitable relief was not "premature" in the ordinary sense of the word. Williamson County's reliance on Monsanto was clearly intended to suggest, as noted at the time, "that suit in the [Court of Federal Claims] is some kind of precondition to suit in district court." ${ }^{43}$ But the Court of Federal Claims is the only forum with jurisdiction to hear takings claims against the federal government in excess of $\$ 10,000 .{ }^{44}$ Monsanto's claim was not barred for being premature; the claim was barred because the company failed to do what the plaintiff in Williamson County did-seek just compensation in a federal court with jurisdiction over the claim.

Stripped of the inapt analogies to Parratt and Monsanto, the only support for the state litigation requirement was Justice Blackmun's self-evident, yet seemingly vacuous, observation that "[t]he Fifth Amendment does not proscribe the taking of property; it proscribes taking without just compensation." ${ }^{45}$ Obviously, plaintiffs do not bring suit for a violation of the Takings Clause unless they can allege a taking without just compensation; that is the gravamen of the complaint. The Court in Williamson County chose to address the following question: What is the proper court to adjudicate takings claims? Justice Blackmun's tautological recitation of the constitutional text sheds no light whatsoever on that issue. ${ }^{46}$ Justice Blackmun only provides the following insight:

40. Monsanto, 467 U.S. at 998-99.

41. Id. at 1001-1004.

42. Id. at 1016-1019.

43. Berger, supra note 24, at 57.

44. The Tucker Act assigns to the Court of Federal Claims jurisdiction over "any claim against the United States founded upon ... the Constitution," 28 U.S.C. 1491(a)(1) (2011), and this jurisdiction is exclusive for claims over $\$ 10,000$. 28 U.S.C. 1346(a)(2) (2013).

45. Williamson Cty. Reg'1 Planning Comm'n v. Hamilton Bank of Johnson City, 473 U.S. 172, 194 (1985).

46. See, e.g., John Martinez \& Karen L. Martinez, A Prudential Theory for Providing a Forum for Federal Takings Claims, 36 ReAl ProP. ProB. \& TR. J. 445, 460 (2001) ("[I]t makes sense that a claimant must ask for and be denied compensation before the judicial machinery may be mobilized to determine whether the government has violated the Just Compensation Clause. However, the person 
The key to this logical puzzle apparently lies in the opinion's assertion that [B]ecause the Constitution does not require pre-taking compensation and is instead satisfied by a reasonable and adequate provision for obtaining compensation after the taking, the State's action here is not "complete" until the State fails to provide adequate compensation for the taking. ${ }^{47}$

By referring to both the county planning commission and the Tennessee state courts as "the State", Justice Blackmun implied some sort of functional identity between the agency committing the taking (the commission) and a possible source of a compensation remedy (the state judiciary). But the identification of the two public entities is plainly spurious. ${ }^{48}$ In most cases, as in Williamson County, takings are effected by actions of the executive branch of the local governmentcity or county boards and commissions. ${ }^{49}$ These entities are legally, functionally, and fiscally distinct from the judicial branch. If Hamilton Bank prevailed in a state, inverse condemnation action against the regional planning commission, the state court would not provide compensation. ${ }^{50}$ Rather, the state court would order the commission to

from whom, or entity from which, the claimant should request compensation, and in what forum, remain undetermined.").

47. Williamson Cty., 473 U.S. at 195 (emphasis added).

48. As Luke Wake has noted, "under this interpretive theory, state courts were viewed as active participants in facilitating a constitutional violation." Luke A. Wake, Righting a Wrong: Assessing the Implications of Knick v. Township of Scott, 14 ChARLESTON L. REV. 205, 217 (forthcoming, Winter 2020). Viewed differently, Williamson County treated local governments as though they were mere appendages of state government. See Robert H. Thomas, Sublimating Home Rule and Municipal Separation of Powers in Knick v. Township of Scott, 47 FORDHAM URB. L.J. 509, 512-13 (2020).

49. See, e.g., Michael B. Kent, Jr., Weakening the "Ripeness Trap" for Federal Takings Claims: Sansotta v. Town of Nags Head and Town of Nags Head v. Toloczko, 65 S.C. L. REV. 935, 945 (2014) ('[I]n most cases, the 'government' will be the state or local agency doing the alleged taking. The state judicial system, by contrast, provides a forum to remedy the uncompensated taking, just like a federal court does.") (footnote omitted).

50. For purposes of this hypothetical, we leave aside the fact that inverse condemnation was not available under Tennessee state law, as Hamilton Bank informed the Court at the time. See Transcript of Oral Argument, Williamson Cty. Reg'l Planning Comm'n v. Hamilton Bank of Johnson City, 473 U.S. 172 (1985) (No. 84-4), 1985 U.S. TRANS LEXIS 76, at 16-18. Compensation for a regulatory taking under Tennessee state law would not be available until nearly 30 years after Williamson County. See Phillips v. Montgomery Cty., 442 S.W.3d 233, 242-44 (Tenn. 2014). 
do so-exactly as a federal court would and, in fact, did. If the foregoing passage in Williamson County read, "the planning commission's action here is not 'complete' until the Tennessee state courts fail to order it to provide adequate compensation for the taking," the non sequitur would have been obvious. A taking without just compensation occurred when the commission denied permits to develop the property and failed to provide compensation for the owner's loss. Thereafter, any court of competent jurisdiction, state or federal, could enforce the terms of the Fifth Amendment and order the commission to pay. The simple truism that the Fifth Amendment proscribes only takings without just compensation offers no insight at all as to the proper court in which compensation should be sought. Yet those words would be seized upon for decades, by federal courts throughout the country, as somehow justifying the dismissal of property owners' federal constitutional claims seeking to establish that their property in fact was taken without just compensation. ${ }^{51}$

The logical flaws and non sequiturs in Williamson County were so many and so glaring that the decision immediately became the target of sharp criticism from both scholars and practitioners. ${ }^{52}$ A steady

51. See, e.g., Downing/Salt Pond Partners, L.P. v. Rhode Island \& Providence Plantations, 643 F.3d 16, 20 (1st Cir. 2011) (finding federal takings claim unripe because "the Fifth Amendment 'does not proscribe the taking of property; it proscribes taking without just compensation."') (quoting Williamson County, 473 U.S. at 194); Peters v. Village of Clifton, 498 F.3d 727, 730 (7th Cir. 2007) (dismissing landowner's regulatory takings claim from federal court as unripe for failure to pursue state litigation because "no constitutional violation occurs until just compensation has been denied." (quoting Williamson County, 473 U.S. at 195 n.13)); Henry v. Jefferson Cnty. Planning Comm'n, 34 F. App'x 92, 95-96 (4th Cir. 2002) (dismissing federal takings claim as unripe under Williamson County's state procedural requirement because "the mere taking of a landowner's property does not violate the Fifth Amendment; the violation occurs only when the property is taken and the landowner has been denied just compensation."); Macene v. MJW, Inc., 951 F.2d 700, 704 (6th Cir. 1991) (finding federal takings claim unripe because where "a state provides an adequate procedure for seeking just compensation, the property owner cannot claim a violation of the Just Compensation Clause until it has used the procedure and been denied just compensation.") (quoting Williamson County, 473 U.S. at 195)); Sinaloa Lake Owners Ass'n v. City of Simi Valley, 882 F.2d 1398, 1402 (9th Cir. 1989) (finding physical takings claim unripe because "“[ $t]$ he Fifth Amendment does not proscribe the taking of property; it proscribes taking without just compensation"') (quoting Williamson County, 473 U.S. at 194), overruled on other grounds by Armendariz v. Penman, 75 F.3d 1311, 1326 (9th Cir. 1996); see also Kathryn E. Kovacs, Accepting the Relegation of Takings Claims to State Courts: The Federal Courts' Misguided Attempts to Avoid Preclusion under Williamson County, 26 ECOLOGY L.Q. 1, 10 n.49 (1999) (listing additional cases); Overstreet, supra note 26, at 117 n.160 (listing additional cases).

52. See Berger, supra note 24, at 39-40; see also Henry Paul Monaghan, State Law Wrongs, State Law Remedies, and the Fourteenth Amendment, 86 COLUM. L. 
stream of critical commentary ensued over the next thirty years. ${ }^{53}$ This continuing interest in the case was fueled, at least in part, by the gradual revelation of unforeseen consequences of the decision-most of them detrimental to the ability of property owners to redress violations of their Fifth Amendment rights.

\section{B. Ripeness or Rot? Williamson County Evolved in Ways Both Unforeseen and Inevitable}

Because the ramifications of Williamson County had not adequately been thought through before the decision was handed down, the opinion evolved in practice in unforeseen ways. Although Justice Blackmun's opinion seemed clear that failure to comply with the new ripeness requirements deprived district courts of Article III jurisdiction to hear a takings claim, ${ }^{54}$ subsequent cases began to refer to the doctrine as a "prudential" rule. ${ }^{55}$ After this development, federal

REV. 979, 989-90 (1986).

53. See generally, e.g., R. S. Radford \& Jennifer Fry Thompson, The Accidental Abstention Doctrine: After Thirty Years, the Case for Diverting Federal Takings Claims to State Court under Williamson County Has Yet to Be Made, 67 BAYLOR L. REV. 567, 567 (2015); Michael M. Berger, The Ripeness Game: Why Are We Still Forced to Play?, 30 Touro L. REV. 297, 297 (2014); J. David Breemer, The Rebirth of Federal Takings Review? The Courts' 'Prudential' Answer to Williamson County's Flawed State Litigation Ripeness Requirement, 30 TOURO L. REV. 319, 319 (2014); Hawley, supra note 29; J. David Breemer, You Can Check Out But You Can Never Leave: The Story of the San Remo Hotel-The Supreme Court Relegates Federal Takings Claims to State Courts Under a Rule Intended to Ripen the Claims for Federal Review, 33 B.C. ENVTL. AfF. L. REV. 247, 247 (2006); Scott A. Keller, Note, Judicial Jurisdiction Stripping Masquerading as Ripeness: Eliminating the Williamson County State Litigation Requirement for Regulatory Takings Claims, 85 TEX. L. REV. 199, 199 (2006); Michael M. Berger \& Gideon Kanner, Shell Game! You Can't Get There from Here: Supreme Court Ripeness Jurisprudence in Takings Cases at Long Last Reaches the Self-Parody Stage, 36 URB. LAW. 671, 671 (2004); J. David Breemer, Overcoming Williamson County's Troubling State Procedures Rule: How The England Reservation, Issue Preclusion Exceptions, and the Inadequacy Exception Open the Federal Courthouse Door to Ripe Takings Claims, 18 J. LAND UsE \& ENVTL. L. 209, 209 (2003); Peter A. Buchsbaum, Should Land Use Be Different? Reflection on Williamson County Regional Planning Board v. Hamilton Bank, in TAKING SIDES ON TAKINGS ISSUES 471 (Thomas E. Roberts ed., 2002); Michael M. Berger, Supreme Bait \& Switch: The Ripeness Ruse in Regulatory Takings, 3 WASH. U. J.L. \& POL'Y 99, 99 (2000); Gregory Overstreet, Update on the Continuing and Dramatic Effect of the Ripeness Doctrine on Federal Land Use Litigation, 20 ZONING \& PLAN. L. REP. 25, 25 (1997).

54. See, e.g., Austin v. City \& Cty. of Honolulu, 840 F.2d 678, 682 (9th Cir. 1988) ("Williamson County affects our jurisdiction to hear takings claims. . 'A court lacks discretion to consider the merits of a case over which it is without jurisdiction. '”) (emphasis added; citation omitted).

55. See, e.g., Suitum v. Tahoe Reg'l Planning Agency, 520 U.S. 725, 733-34 
judges were free to decide whether to adjudicate regulatory takings claims on a case-by-case basis. Although most federal judges continued to decline to do so, a new element of uncertainty was created by the possibility that, in any random case, Williamson County's state litigation requirement might be waived. ${ }^{56}$

Even more troubling - at least to aggrieved property owners - was the Court's decision in City of Chicago v. International College of Surgeons. ${ }^{57}$ That 1997 opinion, which did not so much as mention Williamson County, upheld the jurisdiction of a federal court to adjudicate a regulatory takings claim that washad been removed from state court by the municipal defendant. ${ }^{58}$ City of Chicago thereby created a unique procedural asymmetry: property owners seeking to file takings claims against local jurisdictions were barred from federal court under Williamson County, but City of Chicago guaranteed unimpeded access to federal court for governmental defendants in those same cases who asserted removal jurisdiction under 28 U.S.C. $\S$ 1441(a).

But by far the most damning indictment of Williamson County's slipshod underpinnings was the fact that neither the Court nor any party before it considered the relationship between the new state procedures doctrine and ordinary principles of claim and issue preclusion. ${ }^{59}$ The opinion repeatedly emphasized that the plaintiff's takings claim was not barred outright from federal court. Because the claim was "not yet ripe," 60 it was merely "premature" to file in that forum before utilizing the state courts. ${ }^{61}$ As one Supreme Court litigator put it, "There simply is no rational way for an English

(1997) (explaining Williamson County established "two independent prudential hurdles to a regulatory takings claim brought against a state entity in federal court.") (emphasis added).

56. See, e.g., Yamagiwa v. City of Half Moon Bay, 523 F. Supp. 2d 1036, 110810 (N.D. Cal. 2007) (holding that Williamson County was waived when a municipal defendant removed a takings claim from state to federal court, and then sought to have the case dismissed as unripe).

57. 522 U.S. 156, 156 (1997).

58. Id. at $160-61,174$.

59. Claim preclusion (res judicata) bars the subsequent litigation of claims that were, or could have been, brought in a previous judicial proceeding between the same parties. Issue preclusion (collateral estoppel) bars the subsequent litigation of issues of fact or law that were resolved in a previous judicial proceeding between the parties. regardless of the claims in which they arose. RESTATEMENT (SECOND) OF JUDGMENTS $\S \S 17,27$ (AM. LAW INST. 1982).

60. Williamson Cty. Reg'l Planning Comm'n v. Hamilton Bank of Johnson City, 473 U.S. 172, 197 (1985).

61. Id. at 194 . 
speaking person to read Williamson County other than holding that property owners can satisfy those newly minted ripeness requirements and thereby render their claim ripe for federal court litigation." ${ }^{2}$ The possibility that once a plaintiff unsuccessfully sought compensation in state court the taking claim would be barred from subsequent federal litigation is not hinted at in Williamson County, and was apparently never raised when the case was before the Court. ${ }^{63}$

However, it quickly became clear that the state procedures requirement was incompatible with long-standing preclusion doctrine. Once a Fifth Amendment takings claim has been litigated in state court in compliance with Williamson County, the Full Faith and Credit Act requires federal courts to apply that state's preclusion doctrines to any further litigation between the parties involving the same claim or issues. ${ }^{64}$ In most cases, this would prevent a federal court from hearing a takings claim at all. ${ }^{65}$ The fundamental premise underlying Williamson County's state procedures rule - that submitting a federal takings claim to state court would "ripen" it for subsequent litigation in federal court - turned out to be a procedural impossibility. Far from ripening such a claim, complying with Williamson County would effectively extinguish it. ${ }^{66}$

62. Berger, Supreme Bait \& Switch, supra note 53, at 105; see also Stewart E. Sterk \& Michael C. Pollack, A Knock on Knick's Revival of Federal Takings Litigation, 72 FLA. L. REV. 419 (2020) ("The Williamson County opinion appeared to contemplate that a landowner could ripen a federal court takings claim by seeking all relief available under state law.") To regulatory advocates, the distinction between ripening a claim and being permanently barred from federal court may seem no more than a "quibble over terminology." See John Echeverria, Knick v. Township of Scott: Takings Advocates' Nonsensical Forum Shopping Agenda, CPR BLoG, (Sept. 28, 2018), https://www.progressivereform.org/cpr-blog/knick-v-township-ofscott-takings-advocates-nonsensical-forum-shopping-agenda/

[https://perma.cc/C3HD-2R8V]. But to property owners attempting to enforce their rights under the Fifth Amendment, divining the actual meaning of Williamson County was a matter of some urgency.

63. See Br. for Resp't Hamilton Bank, supra note 35 , at *68-9; Br. for United States, supra note 30; Tr. of Oral Arg., supra note 50; Library of Congress: Harry A Blackmun Papers, Box No. 425, case folder 84-4 (containing Justice Blackmun's notes of issues raised before, during, and after oral argument of Williamson County).

64. 28 U.S.C. $\S 1738$ (2012).

65. See, e.g., Migra v. Warren City Sch. Dist. Bd. of Educ., 465 U.S. 75, 80-85 (1984) (reviewing competing policy objectives of 42 U.S.C. $\S 1983$ and the Full Faith and Credit Act, concluding that allowing litigants to bring their state claims in state court and return to federal court to litigate their federal claims "may seem attractive from a plaintiff's perspective, [but] it is not the system established by '1738."').

66. See, e.g., Berger, Supreme Bait \& Switch, supra note 53, at 102 ("[T] act of ripening a case also ends it."). 
Twenty years after Williamson County was handed down, the High Court finally acknowledged what no one had thought of in 1985: that the practical effect of the state procedures requirement was to permanently deny access to federal court for most plaintiffs with Fifth Amendment takings claims against local governments. In San Remo Hotel v. City and County of San Francisco, the Supreme Court granted certiorari to finally confront the question of whether issue preclusion permanently bars a takings claim from federal court, solely because the plaintiff complied with Williamson County's state procedures requirement. ${ }^{67}$

In language hinting that the plaintiffs were engaged in some kind of procedural trickery, Justice Stevens's unanimous opinion framed the issue as one of "giving losing litigants access to an additional appellate tribunal,"68 and proclaimed that the Ninth Circuit was correct to decline petitioner's invitation to ignore the requirements of [the Full Faith and Credit Act]. ${ }^{\circ 69}$ Absent from the opinion was any explanation of why Fifth Amendment takings plaintiffs should be required to litigate their claims in state court in the first place. Although the Court in San Remo Hotel unanimously agreed that the usual effect of the state procedures rule would be to permanently bar federal constitutional claims from federal court, no attempt was made to ground this outcome in traditional principles of ripeness - or any other doctrine.

San Remo Hotel brought the most disconcerting aspect of Williamson County into sharp focus: over the entire thirty-four years of its existence, neither the Supreme Court nor any lower court applying the state procedures requirement was able to advance any intelligible rationale for the rule. ${ }^{70}$ Moreover, a four-justice concurrence, penned by Chief Justice Rehnquist, objected that "the justifications for [the] state litigation requirement are suspect, while

67. San Remo Hotel, L.P. v. San Francisco, 545 U.S. 323, 326 (2005).

68. Id. at 345 .

69. Id. at $347-48$.

70. Some regulatory advocates have attempted to find a post-hoc grounding for the state procedures rule in principles of federalism. See, e.g., Note, Fifth Amendment-Takings Clause-State Litigation Requirement-Knick v. Township of Scott, 133 Harv. L. Rev. 322, 330 (2019); Stewart E. Sterk, The Demise of Federal Takings Litigation, 48 WM. \& MARY L. REV. 251, 299-300 (2006). However, not only did Williamson County itself make no mention of federalism, such a rationale would negate "the whole point of Section 1983." Michael M. Berger, What's Federalism Got to Do with Regulatory Takings?, 8 BRIGHAM-KANNER PROP. RTS. Conf. J. 9, 30 (2019); see also Radford \& Thompson, supra note 53, at 613-17 (discussing the inapplicability of federalism-based rationales to Williamson County). 
its impact on takings plaintiffs is dramatic" and called for the rule to be reconsidered "[i]n an appropriate case." 71 Yet inexplicably, another fourteen years passed and three of the four San Remo Hotel justices who called for reconsideration left the bench before the Court decided that Knick was the "appropriate case."

\section{Knick Finally Drives a Stake Through Williamson County}

It is remarkable that Williamson County's state litigation requirement remained good law for thirty-four years in light of its lack of doctrinal basis, devasting effect on property owners, and lack of coherent defense from its supporters. Over most of that time, petitions were regularly filed asking the Court to reconsider the rule and just as regularly were denied. ${ }^{72}$ The Court finally determined to remedy its error in Knick v. Township of Scott - a case from the Third Circuit Court of Appeals that seemed rather mundane compared to many that had fallen afoul of Williamson County in the past. ${ }^{73}$

The dispute in Knick stemmed from an ordinance the Township of Scott, Pennsylvania, enacted, requiring all cemeteries to be open and accessible to the public. ${ }^{74}$ Rose Mary Knick was notified that she violated the measure because grave markers were found on her ninetyacre farm, which was decidedly not open to the public. ${ }^{75}$ After unsuccessfully seeking an injunction, Mrs. Knick sued the township in federal court on the grounds that the public access requirement amounted to a taking of her property in violation of the Fifth Amendment. ${ }^{76}$ The district court dismissed the complaint as unripe under Williamson County, and the Third Circuit, while acknowledging that the ordinance was "extraordinary and constitutionally suspect," affirmed. ${ }^{77}$ The Supreme Court granted certiorari "to reconsider the holding of Williamson County that property owners must seek just

71. San Remo Hotel, 545 U.S. at 352 (Rehnquist, C.J., concurring in the judgment).

72. See, e.g., Wayside Church v. Van Buren Cty., 847 F.3d 812, 812 (6th Cir.), cert. denied, 138 S. Ct. 380 (2017); Arrigoni Enters., LLC v. Town of Durham, 18 F. Supp. 3d 188 (D. Conn. 2014), cert. denied, 136 S. Ct. 1409 (2016); Alto Eldorado P'ship v. Cty. of Santa Fe, 634 F.3d 1170 (10th Cir.), cert. denied, 565 U.S. 880 (2011).

73. Knick v. Twp. of Scott, 139 S. Ct. 2162, 2162 (2019).

74. Id. at 2168. .

75. Id.

76. Id. at 2168-69.

77. Id. at 2169 . 
compensation under state law in state court before bringing a federal takings claim."78

Chief Justice Roberts's majority opinion announced what should have been a self-evident rule: "[A] property owner has a claim for a violation of the Takings Clause as soon as a government takes his property for public use without paying for it."79 In overruling the 1985 decision, the Chief Justice noted, "Williamson County was not just wrong. Its reasoning was exceptionally ill founded and conflicted with much of our takings jurisprudence." 80

The Knick Court brushed aside the central fallacy of Williamson County - the conflation of a state's judicial system with local government agencies as a singular conceptual "state" entity. The right to compensation under the Fifth Amendment arises at the time an agency takes private property for public use, regardless of available post-taking remedies and regardless of what a state court might or might not have to say about it. ${ }^{81}$ The opinion gave similarly short shrift to Williamson County's inapt analogy to Monsanto and suits in the Court of Federal Claims, noting bluntly: "The [Williamson County] Court was simply confused." 82 Highlighting the double standard implicit in Williamson County, the Chief Justice noted that the effect of Knick would be to "restor[e] takings claims to the full-fledged constitutional status the Framers envisioned when they included the [Takings] Clause among the other protections in the Bill of Rights." 83

Practitioners and commentators who dealt with the confusion, contradictions, and outright injustices of Williamson County for over three decades found the reasoning of Knick obvious and straightforward. ${ }^{84}$ Nevertheless, Justice Kagan's dissent saw the Williamson County doctrine as unproblematic, even with the retrospective understanding that it permanently bars plaintiffs with

78. Id.

79. Id. at 2170

80. Id. at 2178 .

81. Id. at $2170-71$.

82. Id. at 2174 .

83. Id. at 2170 .

84. See, e.g., R. S. Radford, Best Takings Decision We Should Never Have Needed, S.F. DAILY J., July 3, 2019, at 7 ("The holding in Knick "seems so obvious that it should never have needed to be said."); Michael M. Berger, Ding Dong, the Witch Is Dead!, S.F. DAILY J., June 24, 2019, at 7 ("[T] he clear logic of the majority opinion gives one pause to question why it took ... [34 years] to see the errors at the heart of Williamson County and to acknowledge the unfairness being inflicted on one specific class of constitutional plaintiffs."). 
constitutional claims from seeking a remedy in federal court. ${ }^{85}$ The dissent leaned heavily on a nineteenth century case, Cherokee Nation v. Southern Kansas Railway Co ${ }^{86}$ Cherokee Nation addressed the constitutionality of an Act of Congress authorizing a railroad across part of the Indian Territory and establishing an elaborate, multi-tiered system to appraise the value of the easement taken to provide compensation to the tribe. It was in that context that Justice Harlan's opinion observed:

[The Takings Clause] does not provide or require that compensation shall be actually paid in advance of the occupancy of the land to be taken. But the owner is entitled to reasonable, certain and adequate provision for obtaining compensation before his occupancy is disturbed. Whether a particular provision be sufficient to secure the compensation to which, under the Constitution, he is entitled, is sometimes a question of difficulty. In the present case, the requirements of the Constitution have, in our judgment, been fully met. ${ }^{87}$

These remarks addressed an exercise of direct condemnation, in which compensation to the landowners was expressly acknowledged and provided for in the Act itself. To apply the same language to inverse condemnation, as the Knick dissent does-interpreting it to mean no liability for the taking is incurred until a state court passes on the question of whether any compensation will be paid at all —entails a conceptual leap that could not have been contemplated by the Cherokee Nation Court. ${ }^{88}$

Irrespective of Justice Kagan's misplaced appeal to precedent, the Knick dissent maintained that an alleged violation of the Fifth

85. Knick, 139 S. Ct. at 2180 (Kagan, J., dissenting).

86. See id. at 2182; Cherokee Nation v. S. Kan. Ry. Co., 135 U.S. 641, 659 (1890).

87. S. Kan. Ry. Co., 135 U.S. at 659.

88. Knick, 139 S. Ct at 2182-83 (Kagan, J., dissenting); see also Ilya Somin, Knick v. Township of Scott: Ending a Catch-22 that Barred Takings Cases from Federal Court, CATO SUP. CT. REV., 2018-2019, at 153, 178 ("There can be no such advance assurance of 'reasonable, certain and adequate' compensation in a case where the government denies that any compensation is due in the first place."); Wake, supra note 48, at 229 (Cherokee Nation "would seem to speak only to cases in which the government has acknowledged that it is using the power of eminent domain and has made allowance for the payment of fair market value of the condemned land, as was contemplated with the enactment then in question."). 
Amendment, brought under section 1983, "more properly belongs" in state court because state judges are more familiar with state law. ${ }^{89}$ This argument had already been raised by Justice Stevens in San Remo Hotel, where it was skewered by Chief Justice Rehnquist:

[T]he Court has not explained why we should hand authority over federal takings claims to state courts, based simply on their relative familiarity with local land-use decisions and proceedings, while allowing plaintiffs to proceed directly to federal court in cases involving, for example, challenges to municipal land-use regulations based on the First Amendment, or the Equal Protection Clause..$^{90}$

On a more general level, Justice Kagan's position was rebutted 55 years earlier, in Justice William O. Douglas's concurring opinion in England v. Louisiana State Board of Medical Examiners:

[T]he complexity of local law to federal judges is inherent in the federal court system as designed by Congress. Resolution of local law questions is implicit in diversity of citizenship jurisdiction. Since Erie $R$. Co. v. Tompkins, the federal courts under that head of jurisdiction daily have the task of determining what the state law is. The fact that those questions are complex and difficult is no excuse for a refusal by the District Court to entertain the suit. ${ }^{91}$

But whatever one makes of the view that state judges should adjudicate federal constitutional claims because of their familiarity with the subject matter, it is no longer the law after Knick.

89. Knick, 139 S. Ct at 2187; see also Note, Fifth Amendment-Takings ClauseState Litigation Requirement-Knick v. Township of Scott, supra note 70, at 330 (suggesting that federal judges, as opposed to their state-court counterparts, might be unable to determine the content of a state's common law of property, thereby inadvertently destroying property rights while attempting to protect them).

90. San Remo Hotel, L.P. v. San Francisco, 545 U.S. 323, 350-51 (Rehnquist, C.J., concurring in the judgment) (internal citations omitted).

91. England v. La. State Board of Med. Exam'rs, 375 U.S. 411, 426 (1964) (Douglas, J., concurring). 


\section{The ElEPHANT IN THE COURTROOM-WiLl FEDERAL CoURTS RISE TO THE CHALLENGE?}

\section{A. Both Supporters and Critics of Knick Assume the Decision Will Lead to More Successful Takings Lawsuits}

Although virtually no analysts defended the doctrinal basis of the state litigation requirement during the thirty-four years of Williamson County's existence, many insisted that the rule did no harm because state judges would uphold the constitutional rights of property owners as vigorously as their federal counterparts. ${ }^{92}$ This "presumed parity of state and federal courts for the litigation of federal rights" 93 underlays Justice Stevens's dismissive remark in San Remo Hotel in which he states, "it is entirely unclear why [petitioners'] preference for a federal forum should matter for constitutional or statutory purposes." 94

This narrative evaporated the moment Knick raised the prospect that property owners might once again be allowed to pursue Fifth Amendment takings claims in their choice of forum. Instead of continuing to assert the equivalence of state and federal courts, regulatory advocates portrayed Knick as ushering in extensive new financial liability for local agencies whose restrictive land-use regulations (which would be upheld in state court) could not survive constitutional scrutiny by federal judges. Senator Sheldon Whitehouse railed in The National Law Journal that the Knick Court was acting as "delivery boys for big Republican donor interests." cast as a "big prize" for "big-money developers and regulated industries." "96 These nefarious characters supposedly spent hundreds of millions of dollars in "dark money" to achieve this "massive victory for the partisan donor interests seeking to control our courts." 97 Similarly, Jonathan Zasloff, posting on the Legal Planet blog, labeled Knick the "Roy Cohn case." "98 For those too young to recognize the

92. See, e.g., Kovacs, supra note 51, at 47 ("If state courts can be trusted to protect the interests of criminal defendants, surely they can be trusted to fairly resolve the claims of property owners.").

93. Jamison E. Colburn, Splitting the Atom of Property: Rights Experimentalism as Obligation to Future Generations, 77 GEO. WASH. L. REV. 1411, 1436 (2009).

94. San Remo Hotel, 545 U.S. at 344.

95. Sheldon Whitehouse, Why the 'Knick' Ruling Signals a New Day, NAT'L L. $\mathrm{J}$ (July 24, 2019, $2: 53 \quad$ PM), https:/www.law.com/nationallawjournal/2019/07/24/why-the-knick-rulingsignals-a-new-day/ [https://perma.cc/24WR-8AND].

96. Id.

97. $I d$.

98. Jonathan Zasloff, Roy Cohn Meets the Takings Clause, LEGAL PLANET (Mar. 
reference, Zasloff explained, "Roy Cohn was one of the most disgusting figures of 20th century American law." 99 The reason for these virulent reactions was straightforward: reopening the federal courthouse doors to takings claims meant, according to Zasloff, that "we will start seeing more private property owners winning these cases." 100

Zasloff offered no explanation for why the number of successful takings claims would increase when property owners were once again allowed access to federal courts. Whitehouse broadly implied that federal judges would be more likely to uphold property owners' constitutional rights because the federal judiciary, or a growing portion of it, is corrupt - "handpicked to favor corporations." "101 Never mind that almost none of the takings plaintiffs who have prevailed at the Supreme Court have been corporations, while several corporations and other large business interests have lost. ${ }^{102}$

In addition to his "corporate influence" narrative, Senator Whitehouse advanced a more substantive account of why state court judges would be less likely to uphold property owners' rights than their federal counterparts. He maintained that state courts offer a more difficult forum in which to litigate takings claims because state judges allegedly care more "about things such as affordable housing and environmental protection - stuff Americans want their government to

4, 2019), https://legal-planet.org/2019/03/04/roy-cohn-meets-the-takings-clause/ [https://perma.cc/F8Z8-MLAM].

99. Id.

100. $I d$.

101. Sheldon Whitehouse, Why the 'Knick' Ruling Signals a New Day, NAT'L L. J. (July 24, 2019, $2: 53 \quad$ PM), https://www.law.com/nationallawjournal/2019/07/24/why-the-knick-rulingsignals-a-new-day/ [https://perma.cc/24WR-8AND].

102. Compare, Knick v. Twp. of Scott, 139 S. Ct. 2162 (prevailing plaintiff was a farm owner), Horne v. Dep't of Agriculture, 576 U.S. 350 (2015) (prevailing plaintiff was a raisin grower), Koontz v. St. Johns River Water Mgmt. Dist., 570 U.S. 595 (2013) (prevailing plaintiff was an individual property owner), Palazzolo v. Rhode Island, 533 U.S. 606 (2001) (prevailing plaintiff was an individual property owner), Suitum v. Tahoe Regional Planning Agency, 520 U.S. 725 (1997) (prevailing plaintiff was a widowed homeowner), Lucas v. South Carolina Coastal Council, 505 U.S. 1003 (1992) (prevailing plaintiff was an individual property owner), Dolan v. City of Tigard, 512 U.S. 374 (1994) (prevailing plaintiff was a small business owner), and First English Evangelical Lutheran Church of Glendale v. Cty. of L.A., 482 U.S. 304 (prevailing plaintiff was a local church), with Lingle v. Chevron USA Inc., 544 U.S. 528 (2005) (losing plaintiff was a petroleum refining and distribution corporation), Keystone Bituminous Coal Assoc. v. DeBenedictis, 480 U.S. 470 (losing plaintiff was an association of coal producers), and Penn Central Transp. Co. v. City of New York, 438 U.S. 104 (1978) (losing plaintiff was a major transportation holding company). 
do with its eminent domain power."103 Of course, regulatory takings claims, such as the one in Knick, have nothing to do with the exercise of eminent domain except insofar as the government has chosen not to exercise it. If the Township of Scott wanted to condemn an easement across Mrs. Knick's land for the benefit of the public who wished to view the gravesites on her property, the Township had (and still has) the authority to do so under its power of eminent domain, paying Mrs. Knick the fair market value of the easement in accordance with standard principles of condemnation law. ${ }^{104}$ Regulatory takings, however, involve inverse condemnation-whereby the government imposes a use on private property for the public benefit but declines to pay for it. ${ }^{105}$ The purposes for which the government wants to take the property, so long as they satisfy the "public use" requirement, are immaterial to the constitutional analysis. Stripped of the inapt reference to eminent domain, Senator Whitehouse seemed suggest that state judges are more likely than their federal counterparts to uphold uncompensated takings of property, in contravention of the Fifth Amendment, simply because they approve of the purpose for which the property is taken.

Senator Whitehouse offered no documentation to support his theory of why takings plaintiffs are more likely to lose in state court, but he agrees on this point with many property-rights advocates who expect more rulings in favor of takings claimants now that Knick reopened the federal courthouse doors. For example, Richard Epstein, author of the landmark 1985 book, Takings, ${ }^{106}$ is confident that "[t]his new jurisdictional option will result in some large judgments against local governments, and it doubtless will introduce a welcome note of

\footnotetext{
103. Sheldon Whitehouse, Why the 'Knick' Ruling Signals a New Day, NAT'L L. J. (July 24, 2019, $2: 53 \quad$ PM), https://www.law.com/nationallawjournal/2019/07/24/why-the-knick-rulingsignals-a-new-day/ [https://perma.cc/24WR-8AND]. For a more nuanced hypothesis, see David A. Dana, Not Just a Procedural Case: The Substantive Implications of Knick for State Property Law and Federal Takings Doctrine (Nw. Law \& Econ. Research Paper No. 19-11; Nw. Pub. Law Research Paper No. 19-26) https://ssrn.com/abstract=3508857 or http://dx.doi.org/10.2139/ssrn.3508857 (Knick may "move the courts toward a more property-rights-protective, procompensation version of substantive federal Takings doctrine," one which could "deprive state and local regulators of flexibility that they require for effective adaptation to climate change.").

104. See, e.g., Eminent Domain: A Handbook Of Condemnation LaW 17 (William Scheiderich et al. eds., 2011).

105. See, e.g., SteVen J. Eagle, Regulatory Takings 1-6 (5th ed., 2012).

106. Richard A. EPSTEIn, TAKIngs: Private Property AND THE POWER OF EMINENT DOMAIN (1985).
} 
caution in local governments by exposing them to more powerful legal relief."107

These expectations have an obvious plausibility based on widespread skepticism concerning the objectivity of state courts in adjudicating constitutional claims against local governmental entities. In a classic 1977 article in the Harvard Law Review, Burt Neuborne argued that federal courts are generally more inclined toward federal constitutional litigants for institutional reasons, including their insulation from local political pressures. ${ }^{108}$ Years before Williamson County, William Ryckman observed that property owners were turning to the federal judiciary more frequently to escape "local bias against federal [constitutional] claims," 109 believing that the likelihood of successfully asserting their Fifth Amendment rights would be undermined by "political and psychological pressures affecting state courts." ${ }^{110}$ By its nature, a regulatory takings claim typically entails a landowner seeking to impose financial liability upon a local government. Viewed in that light:

[A]n almost certain prejudice is created by having an elected or appointed state judge, sitting in the same local area as the alleged taking, decide the case. In contrast, federal judges who enjoy life-tenure are far more likely to be removed from local biases. ${ }^{11}$

In those states (the large majority) ${ }^{112}$ where judges must stand for election, "[p]otential bias by state courts is more than just a theoretical problem given the reality that many state judges . . . have close ties to state parties and political leaders who adopt policies that result in regulatory takings." 113 Under the Williamson County regime, many

107. Richard Epstein, A Quiet Revolution in Property Rights, RiCOCHET.COM (July 2, 2019), https://ricochet.com/636016/a-quiet-revolution-in-property-rights/ [https://perma.cc/2GPV-HVRA].

108. Burt Neuborne, The Myth of Parity, 90 HARV. L. REV. 1105, 1120-21 (1977).

109. Ryckman, supra note 30, at 378.

110. Id. at 379 .

111. Overstreet, supra note 26, at 92-93.

112. See State-by-State Summary of Judicial Selection, USLEGAL.COM, https:/courts.uslegal.com/selection-of-judges/state-by-state-summary-of-judicialselection/ [https://perma.cc/ZY45-W6SX].

113. Somin, supra note 88 , at 182; see also Brian T. Hodges, Knick v. Township of Scott, Pa: How a Graveyard Dispute Resurrected the Fifth Amendment's Takings Clause, 60 SANTA ClARA L. REV. 1, 25 (2020) ("Federal judges are typical[ly] viewed as being more removed from local politics than their state counterparts (a vast majority of whom are elected). The need to distance oneself from local politics 
landowners considered the prospect of receiving a fair hearing in state court so poor that they "declined to pursue their rights or ended up throwing in the towel." 114 As Professor Epstein observed in the context of rent regulations in New York, the demise of the state litigation requirement means that "virtually all the constitutional challenges to New York State's new rent laws will be brought in federal court to escape the strong pro-tenant bias that dominates New York state courts." 115

However, while all of these considerations support an expectation that takings litigants will attempt to flee the perceived pro-government bias of state courts - arguably generating the "flood" of new federal litigation Justice Kagan bemoaned in her Knick dissent ${ }^{116}$ - they do not bear directly on the question that aggrieved property owners are most interested in: are those claims likely to fare any better before the federal judiciary? The historical record in that regard is bleak.

\section{B. The Sorry History of Federal-Court Enforcement of the Takings Clause Offers Little Support for That View}

\section{For Decades, Federal Judges Have Freely Expressed Their Distaste for Adjudicating the Constitutionality of Land Use} Restrictions.

Any supposition that federal judges have been waiting eagerly for an opportunity to vindicate the rights of property owners and impose takings liability on local governments is wildly at variance with the existing record. As one commentator observed, "the federal bench's reluctance to decide takings cases and treatment of property rights as secondary to other constitutional rights indicate that the usual

is often pronounced in the context of takings law") (citation omitted); Alicia Gonzalez \& Susan L. Trevarthen, Deciding Where to Take Your Takings Case PostKnick, 49 STETSON L. REV. 539, 566 (2020) ("With land use decisions ... if you are the party whose position is not generally favored in the community, having the case heard in federal court might be preferable.").

114. Robert H. Thomas, Knick Analysis, Part I: After More Than 30 Years, Supreme Court Reopens The Federal Courthouse Door To Property Owners, INVERSECONDEMNATION.COM (June 24, 2019), https:/www.inversecondemnation.com/inversecondemnation/2019/06/after-morethan-30-years-supreme-court-reopens-the-federal-courthouse-door-to-propertyowners.html [https://perma.cc/TY7H-WZZM].

115. Richard Epstein, A Quiet Revolution in Property Rights, RICOCHET.COM (July 2, 2019), https://ricochet.com/636016/a-quiet-revolution-in-property-rights/ [https://perma.cc/2GPV-HVRA].

116. Knick v. Twp. of Scott, 139 S.Ct. 2162, 2189 (2019) (Kagain, J., dissenting). 
assumptions regarding federal courts' sympathies in constitutional cases may not apply in takings cases." 117 While it was presumably intended tongue-in-cheek, Chief Justice Roberts's comment to Mrs.Rose Mary Knick's counsel concerning the consequences of overruling Williamson County was solidly grounded in reality:

[Y]ou can answer the letters that we're going to get from district court judges around the country who are not going to be very happy learning that they now have to adjudicate state inverse condemnation actions, which can be fairly elaborate. ${ }^{118}$

Twenty-five years ago, the late Chief Justice Rehnquist declared that "[w] see no reason why the Takings Clause of the Fifth Amendment, as much a part of the Bill of Rights as the First Amendment or Fourth Amendment, should be relegated to the status of a poor relation."119 Yet that sentiment has not been reflected in any observable change in the long-standing attitudes of many federal judges, that land use disputes are "not terribly important and somewhat beneath them."

Dating back to 1955 , inverse condemnation claims against local governments were routinely litigated in federal courts, ${ }^{121}$ but as the number of such actions skyrocketed in response to increasingly restrictive land use regulations, the keenness of federal judges to resolve cases decreased proportionately. By the time Knick reached the Supreme Court, the National Governors' Association observed that it had been "long recognized that land use disputes present fundamentally local fights that federal courts should not referee" and complained that overruling Williamson County "would demand that federal courts intervene in these common, distinctly local controversies." 122 The tone of this passage - that applying the text of

117. Kovacs, supra note 51, at 46 (1999); see also Laura D. Beaton \& Matthew D. Zinn, Knick v. Township of Scott: A Source of New Uncertainty for State and Local Governments in Regulatory Takings Challenges to Land Use Regulation, 47 FORDHAM URB. L.J. 623, 625 (2020) ("[H] istorically, lower federal courts have been deeply reluctant to referee land use disputes and may lack enthusiasm for a new category of claims in that field.").

118. Transcript of Oral Argument at 23, Knick v. Twp. of Scott, 139 S.Ct. 2162 (2019) (No. 17-647).

119. Dolan v. City of Tigard, 512 U.S. 374, 392 (1994).

120. Overstreet, supra note 26, at 103 (citation omitted).

121. See Sixth Camden Corp. v. Twp. of Evesham, 420 F. Supp. 709, 721 (D. N.J., 1976) (citing cases).

122. Brief for National Governors Association et al. as Amici Curiae Supporting 
the Constitution to protect landowners' rights would comprise a somewhat distasteful burden on federal judges - mirrors the language of many decisions over the past forty years.

Federal judges have expressed a special disdain for reviewing the application of zoning regulations for compliance with the Constitution, often sounding as though they consider the task unbecoming the dignity of their office. Two years before Williamson County, the Seventh Circuit objected that the "availability of federal review of every zoning decision would only serve to further congest an already overburdened federal court system." ${ }^{23}$ Another panel of the same circuit acknowledged that it was "conceivable that a federal lawsuit might arise out of a zoning dispute" but nevertheless grumbled that " $[\mathrm{t}]$ he idea that constitutional rights are implicated in this quarrel over the zoning rules is not one to which we would like to become accustomed." 124

By the 1980s, the federal judiciary developed a virtual mantra, repeated as often as necessary, to the effect that "federal courts do not sit as zoning boards of review." 125 As the Ninth Circuit memorably noted, it was necessary to "guard against the federal courts becoming the Grand Mufti of local zoning boards."126 Never was this theme hammered home more brutally than by Judge Easterbrook in River Park, Inc. v. City of Highland Park: ${ }^{127}$

Federal Courts are not boards of zoning appeals. This message, oft repeated, has not penetrated the consciousness of property owners who believe that federal judges are more hospitable to their claims than state judges. Why they should believe this we haven't a clue; none has ever prevailed in this circuit. ${ }^{128}$

\footnotetext{
Respondents at 30-31, Knick v. Twp. of Scott, 139 S. Ct. 2162 (2019) (No. 17-647).

123. Scudder v. Town of Greendale, 704 F.2d 999, 1003 (7th Cir. 1983).

124. Albery v. Reddig, 718 F.2d 245, 251 (7th Cir. 1983).

125. Spence v. Zimmerman, 873 F. 2d 256, 262 (11th Cir. 1989); see also Raskiewicz v. Town of New Boston, 754 F.2d 38, 44 (1st Cir.1985) ("federal courts do not sit as a super zoning board or zoning board of appeals").

126. Hoehne v. Cty of San Benito, 870 F.2d 529, 532 (9th Cir. 1989).

127. See generally, 23 F.3d 164, 164 (7th Cir. 1994).

128. $I d$. at 165 (emphasis added).
} 


\section{Abstention Offered an Inviting Way for Federal Courts to Avoid Adjudicating Takings Cases}

One reason no land-use takings claims have prevailed in Judge Easterbrook's Seventh Circuit (and very few in any other circuit) is that federal judges became adept, even before Williamson County, at diverting these cases to state court. As Michael Berger pointed out, when Williamson County was handed down, it did not represent the beginning of a doctrine of shunting takings cases to state court; rather, it was the culmination of that doctrine. ${ }^{129}$

Before 1985, the preferred method employed by federal courts to avoid adjudicating takings claims in land use cases was abstention. ${ }^{130}$ In the Ninth Circuit, federal courts began invoking Pullman abstention to avoid adjudicating these cases even before it was possible to bring them under 42 U.S.C. $\S 1983 .{ }^{131}$ There are two requirements for abstaining under the Pullman doctrine in the Ninth Circuit. ${ }^{132}$ First, the complaint must touch on "a sensitive area of social policy upon which the federal courts ought not to enter unless no alternative to its adjudication is open" (in Pullman, the racial composition of sleepingcar crews). ${ }^{133}$ Second, the case must involve an unsettled or "doubtful" question of state law, the resolution of which may terminate the controversy without reaching the federal constitutional issue (in Pullman, the meaning of Article 6445 of the Texas Civil Statutes,

129. See Berger, supra note 84.

130. See Berger, Supreme Bait \& Switch, supra note 53, at 100-01 ("In the old days, judges issued abstention orders when property owners had the temerity to seek federal court application of the federal constitution. Those orders required the owners to repair to state court to see whether resolution of state law issues might moot or, at least, confine the federal issues. This shunted many regulatory taking cases into state courts.") (Footnotes omitted). The history of pre-Williamson County abstention in regulatory takings cases presented in this section is related in more detail in Radford \& Thompson, supra note 53, at 597-608.

131. See, e.g., Rancho Palos Verdes Corp. v. City of Laguna Beach, 547 F.2d 1092, 1094 (9th Cir. 1976). Although states and state agencies are not "persons" subject to suit under Section 1983, municipalities and other local governmental entities such as school districts were brought within the scope of the section by Monell v. Dep't of Soc. Servs., 436 U.S. 658 (1978).

132. The Pullman doctrine stems from R.R. Comm'n of Tex. v. Pullman Co., 312 U.S. 496 (1941), a case that challenged a Texas Railroad Commission regulation requiring that sleeping cars on Texas trains be operated by (white) conductors, rather than by (African-American) porters. The Supreme Court ordered a federal district court to abstain from issuing an injunction pending a determination in state court of the scope and meaning of the Texas statute under which the regulation was issued. The requirements for applying the doctrine in the Ninth Circuit were set forth in Canton v. Spokane Sch. Dist. No. 81, 498 F.2d 840, 845 (9th Cir. 1974).

133. Pullman, 312 U.S. at 498. 
under which the Commission claimed authority to issue the regulation). ${ }^{134}$ That neither of the required elements would be implicated in a typical regulatory takings claim did not deter federal judges from routinely invoking the doctrine when such cases came before them.

As early as 1976, courts in the Ninth Circuit determined that any litigation involving local land use regulations, by definition, touched upon a "sensitive area of social policy," and began ordering abstention on that basis alone. ${ }^{135}$ The other Pullman requirement an unsettled question of state law that might resolve the controversy, effectively fell out of the equation. A 1982 California study found that none of the federal judges who ordered Pullman abstention in land use cases "specified the unclear question of state law that supported abstention." 136 Yet appellate judges in the circuit were so eager to avoid grappling with these claims that invocations of Pullman abstention were upheld even when the trial court identified no state law question whatsoever that could be resolved so as to moot the federal constitutional issue. ${ }^{137}$ On more than one occasion, Ninth Circuit panels suggested that the existence of a possibly determinative state-law claim was sufficient to justify Pullman abstention in takings cases even if the claim was not raised and therefore not at issue in the litigation. ${ }^{138}$ These rulings lend credence to speculation by the author

134. Id. at 498-500.

135. Rancho Palos Verdes Corp., 547 F.2d at 1094.

136. Theodore Eisenberg, Section 1983: Doctrinal Foundations and an Empirical Study, 67 CoRnell L. REV. 482, 541-42 (1982); see also Note, Land Use Regulation, the Federal Courts, and the Abstention Doctrine, 89 YALE L.J. 1134, 1149 (1980) (suggesting that only a minority of land use cases in federal courts involve unclear state issues that affect constitutional claims); Brian W. Blaesser, Closing the Federal Courthouse Door on Property Owners: The Ripeness and Abstention Doctrines in Section 1983 Land Use Cases, 2 HofSTRA PROP. L.J. 73, 86 (1988) ("In the majority of the decisions that apply Pullman abstention, the courts have not addressed the extent to which the state law question is unsettled.").

137. See Newport Invs., Inc. v. City of Laguna Beach, 564 F.2d 893, 895 (9th Cir. 1977) ("The district judge obviously believed, as we do, that the California courts are fully capable of making a proper determination of the particular issues that they should undertake, in the first instance, to resolve."). Similarly, in Rancho Palos Verdes Corp., 547 F.2d at 1095, the Ninth Circuit affirmed Pullman abstention based on the general observation that "California courts have yet to decide the precise extent to which the state and its municipalities may limit the development of private property."

138. See, e.g., Santa Fe Land Improvement Co. v. City of Chula Vista, 596 F.2d 838, 840 (9th Cir. 1979) (abstaining in part because "the state courts may possibly find that the city has exceeded its authority based upon Cal. Gov't Code $\S 65912$... - That Santa Fe did not specifically raise the question does not foreclose consideration of the issue as a basis for abstention.") (emphasis added). Accord, C- 
of the study cited above that the federal courts' "eagerness to dispose of cases outweigh[ed] any legitimate effort to adhere to established doctrine."139 This eagerness was nowhere revealed more explicitly than in $C$-Y Development Co. v. City of Redlands: "were we to vacate the abstention order and remand for proceedings on the merits, the district court would need to decide the difficult questions of whether a taking had occurred and what constitutional remedy or remedies [were] required." "140 In other words, the court would be required to exercise its Article III jurisdiction in the same manner as any other court adjudicating any other constitutional claim.

The Ninth Circuit continued employing Pullman abstention, even after Williamson County was decided, to dispose of takings claims that were not barred by the state litigation requirement. ${ }^{141}$ In a 1996 case, Sinclair Oil Corp. v. County of Santa Barbara, ${ }^{142}$ the appellate panel remarkably acknowledged that "we cannot appropriately direct the district court to refrain from exercising its jurisdiction over this litigation solely because the suit involves an inverse condemnation action." "143 But the court did so anyway, finding the claim suitable for abstention because it involved land use planning, and the outcome of a trial in state court would be uncertain. ${ }^{144}$

Federal courts in other circuits occasionally invoked Pullman abstention to avoid adjudicating takings claims but not as systematically as the Ninth Circuit. ${ }^{145}$ Beginning in 1972, the Fourth Circuit also expressed a "strong judicial preference" to abstain from

Y Dev. Co. v. City of Redlands, 703 F.2d 375, 378 (9th Cir. 1983) (speculating that a state court might rule in favor of the landowner under $\S 65912$ " [a]lthough $C-Y$ has not raised the point.") (emphasis added).

139. Eisenberg, supra note 137, at 542.

140. Redlands, 703 F.2d at 380.

141. In addition to the rare case in which Williamson County was waived, some facial takings claims were considered to be exempt from the state litigation rule. See, e.g., Sansotta v. Town of Nags Head, 724 F.3d 533, 544-47 (4th Cir. 2013) (state litigation requirement waived by defendant's removal of takings claim from state to federal court); Cashman v. City of Cotati, 374 F.3d 887, 892 n.6 (9th Cir. 2004) (facial takings claim brought under "failure to substantially advance" theory exempt from state litigation requirement).

142. 96 F.3d 401 (9th Cir. 1996).

143. Id. at 410.

144. Id. at 409-410. As this case illustrates, in the 34 years between Williamson County and Knick, federal courts could choose between dismissing takings claims because state courts offered a "reasonable, certain and adequate" means of obtaining compensation, or abstaining from adjudicating them in part because it was highly uncertain whether state courts would in fact require compensation to be paid.

145. See, e.g., Sea Cabin on the Ocean IV Homeowners Ass'n v. City of N. Myrtle Beach, 828 F. Supp. 1241, 1249-50 (D.S.C. 1993). 
adjudicating land-use takings cases. ${ }^{146}$ Although an early district court opinion cautioned that abstention must be based on something more than a mere "visceral aversion to our Article III obligation to adjudicate," 147 that admonition was quickly forgotten. After briefly toying with other options, Fourth Circuit courts began freely applying Burford abstention to avoid adjudicating regulatory takings claims against local governments. ${ }^{148}$

The Burford doctrine offered one major advantage over Pullman abstention - from the perspective of federal courts with a "visceral aversion" to becoming involved in messy local constitutional squabbles. Under Pullman, the abstaining federal court retains jurisdiction over the case during the pendency of state court proceedings to ensure that the constitutional issue is mooted or resolved; whereas under Burford, the federal court dismisses the case outright, in favor of state court adjudication. ${ }^{149}$ The corresponding disadvantage was that Burford was obviously inapplicable to most land use takings cases. Burford applies in cases involving complex, uniform, and statewide procedures governing an important state interest - such as Texas's method of allocating oil drilling rights in the titular case - that could be disrupted by the issuance of a federal injunction. ${ }^{150}$ Applying Burford to avoid adjudicating local land use disputes ignores the most crucial element of the doctrine's rationale for abstention. ${ }^{151}$ Nevertheless, by the time Williamson County was

146. Blaesser, supra note 137 , at 100.

147. Donohoe Constr. Co. v. Md.-Nat'l Cap. Park \& Plan. Comm'n, 398 F. Supp. 21, 30 (D. Md. 1975).

148. See Pomponio v. Fauquier Cty. Bd. of Supervisors, 21 F.3d 1319, 1327 (4th Cir. 1994) ("Other than the initial variation in our decisions generated by the application of Thibodaux in [Fralin \& Waldron, Inc. v. City of Martinsville, 493 F.2d 481 (4th Cir. 1974)], we have applied Burford abstention to land use and zoning cases."). The Burford doctrine derives from Burford v. Sun Oil Co., 319 U.S. 315 (1943).

149. See ERWIn ChEMERINSKy, FEDERAL Jurisdiction 836 (6th ed. 2012).

150. See Burford, 319 U.S. at 320, 325, 333-34; see also CHEMERINSKY, supra note 150, at 833; LARRY W. YACKLE, FEDERAL COURTS 512 (3d ed. 2009) ("[Burford] [a]bstention is warranted if the exercise of federal jurisdiction will seriously interfere with coordinated state regulatory schemes in which administrative agencies and state courts function as partners to bring technical expertise to bear on peculiarly complex and important local matters - involving at least some questions of state regulatory law.").

151. See also Note, supra note 137, at 1151-52.

[A]bstention is more appropriate in cases involving state rather than purely local land use policies. A lesser degree of deference toward local policies is appropriate because local governments are not restrained by the plurality of interests that compete at the state level and can more easily be manipulated to further narrow, 
delivered, Fourth Circuit courts were abstaining in virtually all regulatory takings cases under a hybrid Pullman-Burford rationale, requiring no uncertainty in state law or any need for statewide uniformity and dismissing the claims outright simply because land use policies were deemed to be "a particularly sensitive local matter."152 In one especially extreme rhetorical flight, the Fourth Circuit in Pomponio v. Fauquier County Board of Supervisors justified abstention by declaring, "We can conceive of few matters of public concern more substantial than zoning and land use laws"-an assertion that could hardly be taken seriously. ${ }^{153}$ While applying Burford abstention to clear takings cases from their calendars, federal judges in the Fourth Circuit were routinely adjudicating constitutional challenges to the desegregation efforts of local school districts. ${ }^{154}$ Taken literally, the quoted passage from Pomponio implies that courts in the circuit chose to exercise jurisdiction over these cases because the operation and racial composition of local schools was considered a matter of less substantial public concern than the application of zoning laws. It seems far more plausible that the opposite was true, and the widespread practice of abstaining in land-use takings cases was based on nothing more than the fact that federal courts "simply do not like to hear them." 155

Since Williamson County was decided, both constitutional scholars and the Supreme Court have expressed serious reservations about the viability of abstention as a tool for federal courts to decline exercising their jurisdiction over takings cases. As Professor Yackle notes in his text on federal courts, "[I]f the point of $\S 1983$ is to empower federal courts to enforce federal rights that state courts may fail to respect, it is hard to justify curtailing federal judicial authority on the theory that state courts are, after all, perfectly reliable." ${ }^{156}$ In New Orleans Public Service, Inc. v. Council of the City of New Orleans ("NOPSI"), ${ }^{157}$ the Supreme Court rejected the use of Burford abstention in cases analogous to regulatory takings claims, emphasizing that "there

parochial interests.

152. Blaesser, supra note 137 , at 101.

153. 21 F.3d 1319, 1327 (4th Cir. 1994).

154. See generally, e.g., Belk v. Charlotte-Mecklenburg Bd. of Educ., 269 F.3d 305, 305 (4th Cir. 2001) (applying Equal Protection Clause to local school district's desegregation plan).

155. Overstreet, supra note 26, at 93.

156. Yackle, supra note 151, at 521.

157. New Orleans Pub. Serv., Inc. v. Council of New Orleans, 491 U.S. 350 (1989). 
is ... no doctrine requiring abstention merely because resolution of a federal question may result in the overturning of a state policy." "158 Even more closely on point was the Court's further comment in the same decision that "there is no doctrine that the availability ... of state judicial proceedings excludes the federal courts." ${ }^{" 159}$ Finally, Justice O'Connor's unanimous opinion in Quackenbush v. Allstate Insurance Co. ${ }^{160}$ reminded the lower federal courts that the doctrine of abstention was rooted in equity, and "federal courts have the power to dismiss or remand cases based on abstention principles only where the relief being sought is equitable or otherwise discretionary." ${ }^{161}$ Because the plaintiffs in Quackenbush sought damages instead of equitable relief, the Court found the use of Burford abstention "unwarranted." 162 Presumably, the same reasoning would ban the use of any variety of abstention in cases seeking damages, including takings claims pursuing just compensation.

Nevertheless, in spite of what seems to be the Court's clear trend of disfavoring abstention, the amicus brief filed by the National Governors Association in Knick warned that if the state litigation requirement was no longer available, federal judges would likely resume their former practice avoiding takings claims: "[I]f Williamson County is overturned, the federal courts are likely to shunt much of that litigation over state law questions back to the state courts.... [Abstention] will happen, and the federal courts' demonstrated reluctance to referee land-use disputes suggests it will happen frequently." 163 For this prediction to materialize, creative

158. Id. at 363 (quoting Zablocki v. Redhail, 434 U.S. 374, 380 n.5 (1978)).

159. Id. at 373 .

160. 517 U.S. 706,732 (1996).

161. Id. at 731 (emphasis added).

162. Id.

163. Knick v. Twp. of Scott, No. 17-647, Brief of Amici National Governors Association, et al., In Support of Respondents, at 31-33 (emphasis in original). Several post-Knick commentators have echoed this prediction, although none have explained how a typical inverse condemnation claim could meet any of the Supreme Court's current criteria for abstention. See Beaton \& Zinn, supra note 118, at 63637; Hodges, supra note 114, at 28; Steven Eagle, Takings As Compulsory Purchase of Commercial Units (March 4, 2020), BRIGHAM-KANNER PROP. RTS. J., forthcoming. Available at SSRN: https://ssrn.com/abstract=3548934; John Echeverria, Knick v. Township of Scott: A Procedural Boost for Takings Claimants, ABA SECTION OF ENVIRONMENT, ENERGY, AND Resources (Dec. 20, 2019), https://www.americanbar.org/groups/environment_energy_resources/publications/t rends/2019-2020/january-february-2020/knick-vs-township/

[https://perma.cc/DH2G-38W6]; Dwight Merriam, Rose Mary Knick and the Story of Chicken Little, 47 FordHAM URB. L.J. 639, 650-51 (2020). 
federal judges would have to find a way to circumvent the holdings of NOPSI and Quackenbush. ${ }^{164}$ What is not clear, however, is whether that would be worse for takings plaintiffs than having the federal judiciary decide their cases on the merits.

3. The Mousetrap at the End of the Maze: Few Takings Claims That Have Actually Been Adjudicated in Federal Court Have Prevailed

The rampant misuse of abstention, coupled with dismissals under Williamson County, greatly limited the proportion of takings cases federal courts have adjudicated over the past fifty years. Nevertheless, the number of federal takings cases that have been decided on the merits over this time is significant. Examining the outcome of these lawsuits suggests that Knick's promise of access to federal courts is unlikely to lead to a tsunami of rulings imposing financial liability on local governments.

The main impediment to effective protection of the Fifth Amendment rights of property owners is the lack of any definitive, objective standard of what constitutes a regulatory taking. Justice Holmes's 1922 bromide that "if regulation goes too far, it will be recognized as a taking" "165 is often ridiculed for its lack of substance, but in fact, the Supreme Court has made virtually no progress in refining more consistent or predictable principles to guide courts and litigants in this field.

The Court established two categories of so-called "categorical" takings that apply to regulations that authorize a permanent physical occupation of property ${ }^{166}$ or deprive it of all economically viable use. ${ }^{167}$ But the Court subsequently narrowed those holdings to the point that they can have little, if any, practical application. ${ }^{168}$ The vast

164. In fact, in the first known instance of post-Knick abstention, a federal judge in the Ninth Circuit simply reverted to the pre-Williamson County practice of abstaining under Pullman because "[1] and use planning is a sensitive area of social policy" and the outcome of state-court litigation would be uncertain. Neither NOPSI nor Quackenbush were so much as mentioned. See EHOF Lakeside II, LLC v. Riverside Cnty. Transp. Comm'n, et al., Case 5:19-cv-01693-JGB-SHK, Order on Motion to Abstain 4 (C.D. CA, Nov. 27, 2019).

165. Pennsylvania Coal Co. v. Mahon, 260 U.S. 393, 415 (1922).

166. Loretto v. Teleprompter Manhattan CATV Corp., 458 U.S. 419, 426 (1982).

167. Lucas v. S.C. Coastal Council, 505 U.S. 1003, 1015 (1992).

168. See Tahoe-Sierra Preservation Council, Inc. v. Tahoe Regional Planning Agency, 535 U.S. 302, 330-32 (2002) (limiting Lucas takings to those that permanently deprive property of all value); Yee v. City of Escondido, 503 U.S. 519, 526-32 (1992) (finding no taking under Loretto so long as owner may be allowed to put occupied property to some other use). A 2017 study of approximately 1,700 
majority of takings claims are therefore brought under what the Court has described as the "polestar" of its takings jurisprudence-Penn Central Transportation Co. v. City of New York. ${ }^{169}$

In Penn Central, the Court attempted to set out a framework for determining when property regulations "go too far" and effect a taking, but it failed to enunciate any objective standards for accomplishing that task. ${ }^{170}$ The best the Court could manage was to state, "The economic impact of the regulation on the claimant, and particularly, the extent to which the regulation has interfered with distinct investment-backed expectations are, of course, relevant considerations. So, too, is the character of the governmental action."171 Because this terminology is so vague, commentators cannot agree on how many "relevant considerations" the Court intended to set forth for analysis. ${ }^{172}$ As Steven Eagle put it, "The difficulty for lawyers is figuring out how judges would apply Penn Central to their particular

categorical takings claims brought under Lucas found that only 27 succeeded - a litigation success rate of slightly more than 1.5 percent. See Carol Necole Brown \& Dwight H. Merriam, On the Twenty-Fifth Anniversary of Lucas: Making or Breaking the Takings Claim, 102 IOWA L. REV. 1847, 1848 (2017).

169. 438 U.S. 104, 104 (1978); see Palazzolo v. Rhode Island, 533 U.S. 606, 63234 (2001) (O’Connor, J., concurring) ("Our polestar . . . remains the principles set forth in Penn Central.").

170. See, e.g., R. S. Radford \& Luke A. Wake, Deciphering and Extrapolating: Searching for Sense in Penn Central, 38 Ecology LQ 731, 732 (2011) ("Penn Central enunciates at best a tenuous, ad hoc approach to assessing takings liability."); Mark Fenster, The Stubborn Incoherence of Regulatory Takings, 28 STAN. ENVTL. L. J. 525, 527 (2009) (attributing the Supreme Court's lack of a predictable takings doctrine to "Penn Central's inherent messiness"); R. S. Radford, Instead of a Doctrine: Penn Central as the Supreme Court's Retreat from the Rule of Law, in Rule OF LAW IN THE NeW MillenNiUm 173, 175 (K. Padmaja, ed., 2007) ("It is no exaggeration to describe [the Penn Central] standards as "inscrutable."'); Lise Johnson, Note, After Tahoe Sierra, One Thing Is Clearer: There Is Still a Fundamental Lack of Clarity, 46 ARIZ. L. REV. 353, 360 (2004) (recognizing the unworkable nature of the Penn Central test); Eric R. Claeys, Takings, Regulations, and Natural Property Rights, 88 CoRNELL L. REV. 1549, 1557 (2003) ("the Penn Central approach is admittedly standardless"); Michael M. Berger, Tahoe Sierra: Much Ado About-What?, 25 U. HAW. L. REV. 295, 314 (2003) (referring to the Penn Central balancing test as an "unworkable ... lot-by-lot, fact-by-fact method of adjudication ... so fraught with uncertainty that landowners must often litigate to the highest court that will hear them out to determine whether they have even properly stated a claim on which relief can be granted.").

171. Penn Central, 438 U.S. at 124 (citation omitted).

172. See, e.g., Steven J. Eagle, The Four-Factor Penn Central Regulatory Takings Test, 118 PENN ST. L. REV. 601 (2014) (analyzing Penn Central as a four-factor test for takings liability). 
facts. The difficulty for judges is figuring out what Penn Central really means." 173

The record suggests that what Penn Central really means to most federal judges is that the government wins. In 2013, Adam Pomeroy published a comparative analysis of the treatment of Penn Central claims in the First, Ninth, and Federal Circuits. ${ }^{174} \mathrm{He}$ found that, in the three Circuits combined, only four plaintiffs prevailed on the merits on a regulatory takings claim under Penn Central. ${ }^{175}$ None of the four cases challenged the constitutionality of land use regulations, and only one (brought against the federal government) involved real property at all. ${ }^{176}$ Pomeroy's data showed that while the rate of success for takings claims in the district courts was low to begin with (around $18 \%$ ), those relatively few rulings in favor of plaintiffs were likely to be reversed on appeal. ${ }^{177}$

Although the language of Penn Central seems to imply that courts should balance, or at least compare, three different aspects of a restrictive land use regulation-its "character," its economic impact, and its effect on a landowner's investment-backed expectationsfederal judges have shown a marked tendency to decide takings cases in favor of the government if any one of these factors weighs in the defendant's favor. ${ }^{178}$ An especially pernicious development in the 1990s was the widespread use of Penn Central's reference to investment-backed expectations to defeat takings claims on nothing more than a showing that the property in question (or type of property in question) was subject to some degree of regulation before the owner acquired title or sought approval for development. ${ }^{179}$ This doctrine, which came to be called the "Notice Rule," 180 became so extreme that some federal courts dismissed takings claims on the basis that the

173. Steven Eagle, Penn Central and Its Reluctant Muftis, 66 BAYLOR L. REV. 1, 2 (2014); see also Luke A. Wake, Check Your Rights at the Door: Rethinking Confiscatory Regulation (Aug. 14, 2019), at 7, https://ssrn.com/abstract=3437488 [https://perma.cc/FMM8-NL34], ("[O]ne might even argue that the Penn Central test provides no judicially manageable standard at all.").

174. See Adam R. Pomeroy, Penn Central After 35 Years: A Three Part Balancing Test or a One Strike Rule?, 22 FED. CIR. B.J. 677 (2013).

175. Id. at 692 .

176. $I d$. at $694-95$.

177. Id. at 697-98.

178. Id. at 689.

179. See generally, R. S. Radford \& J. David Breemer, Great Expectations: Will Palazzolo v. Rhode Island Clarify the Murky Doctrine of Investment-Backed Expectations in Regulatory Takings Law?, 9 N.Y.U. ENVTL. L.J. 449 (2001).

180. See, e.g., Steven J. Eagle, The Regulatory Takings Notice Rule, 24 U. HAW. L. REV. 533, 533 (2002). 
landowner should have known (in the court's opinion) that restrictions were likely to be imposed in the future. ${ }^{181}$

In Palazzolo v. Rhode Island, the Supreme Court finally stepped in to put an end to these abuses. ${ }^{182}$ This case involved wetland regulations that prevented Anthony Palazzolo from making any beneficial use of eighteen acres of undeveloped property. ${ }^{183}$ Palazzolo originally purchased the land through a closely-held corporation, but when the corporate charter was revoked in 1978, he personally acquired title to the parcel by operation of law. ${ }^{184}$ The Rhode Island Supreme Court held that Palazzolo could not claim the regulations effected a taking under Penn Central because the restrictive regulatory scheme was already in place by the time he acquired title in his own name. ${ }^{185}$ Accordingly, the State's highest court affirmed the trial court's conclusion that "a regulatory takings claim may not be maintained whe[n] the regulation predates the acquisition of the property."186

Granting certiorari, the Supreme Court forcefully repudiated the rule that a "purchaser or a successive title holder" can be barred from challenging a previously enacted regulation under the Takings Clause simply by having notice of the restrictions. ${ }^{187}$ Recognizing that such a doctrine would effectively allow the government to regulate private property out of existence by the mere passage of time, Justice Kennedy memorably declared, "[t]he State may not put so potent a Hobbesian stick into the Lockean bundle." "188 He continued:

Were we to accept the State's rule, the post-enactment transfer of title would absolve the State of its obligation to defend any action restricting land use, no matter how extreme or unreasonable. A State would be allowed, in

181. See Dist. Intown Props., Ltd. P'Ship v. Dist. of Columbia, 198 F.3d 874, 883 (D.C. Cir. 1999) (holding that the plaintiffs "could have reasonably expected" that they would not be able to develop their commercial real estate, given the existence of a law authorizing the Fine Arts Commission to make recommendations about actions affecting the public values of the National Zoo); Good v. United States, 189 F.3d 1355, 1363 (Fed. Cir. 1999) ("In light of the growing consciousness of and sensitivity toward environmental issues, [the landowner] must also have been aware that standards could change to his detriment").

182. 533 U.S. 606, 606 (2001).

183. Id. at 615 .

184. Id. at 613-14.

185. Id. at 616.

186. Palazzolo v. Rhode Island, 746 A.2d 707, 715 (R.I. 2000).

187. Palazzolo, 533 U.S. at 626.

188. Id. at 627. 
effect, to put an expiration date on the Takings Clause. This ought not to be the rule. Future generations, too, have a right to challenge unreasonable limitations on the use and value of land. ${ }^{189}$

Writing in concurrence, Justice O'Connor emphasized that "the Rhode Island Supreme Court erred in effectively adopting the sweeping rule that the preacquisition enactment of the use restriction ipso facto defeats any takings claim based on that use restriction."190 She elaborated that the date of adoption of restrictive land use regulations should rightly be considered as merely one factor among many in determining the impact of the restrictions on a given owner's investment-backed expectations - which in turn remained "one of a number of factors that a court must examine" to determine whether there has been a Penn Central taking. ${ }^{191}$

The Palazzolo Court was emphatic in holding that mere notice of the prior existence of regulation, without more, is not sufficient to defeat a takings claim under Penn Central. ${ }^{192}$ But the allure of the now-discredited Notice Rule as a quick and simple way to dispose of such cases, while supposedly complying with Penn Central, proved too much for some federal courts to resist. The Ninth Circuit, in particular, exhumed that doctrine and enshrined it as the law of the circuit, notwithstanding its express repudiation in Palazzolo.

4. Guggenheim v. Goleta Illustrates the Lengths to Which Federal Courts Have Gone to Avoid Imposing Takings Liability on Local Governments

The paradigm example of the Ninth Circuit's resurrection of prePalazzolo notice doctrine is Guggenheim v. City of Goleta, a challenge to the constitutionality of rent control in a mobile home park. ${ }^{193}$

189. Id.

190. Id. at 632 (O’Connor, J., concurring).

191. Id. at $633-36$.

192. Justice Scalia would have gone further, opining that, in his view, "the fact that a restriction existed at the time the purchaser took title ... should have no bearing upon the determination of whether the restriction is so substantial as to constitute a taking. The 'investment-backed expectations' that the law will take into account do not include the assumed validity of a restriction that in fact deprives property of so much of its value as to be unconstitutional." Id. at 637 (Scalia, J., concurring).

193. Guggenheim I, 582 F.3d 996, 999 (9th Cir. 2009), reh'g en banc granted, vacated by, Guggenheim II, 638 F.3d 1111 (9th Cir. 2010). 
Regulations of this sort are widespread in California, and their effect in practice is to carry out what two appellate judges have aptly described as a "naked" wealth transfer from park owners to their tenants. ${ }^{194}$ This process has been well documented by economists, both theoretically and empirically, for more than thirty years. ${ }^{195}$

The Guggenheim plaintiffs challenged an especially stringent rent ordinance that created such a windfall for their tenants that nearly $90 \%$ of the resale value of coaches sold in the park consisted of the discounted present value of below-market rents. ${ }^{196}$ This one-time wealth transfer to residents who owned coaches in the park at the time rent control was enacted came at the cost of up to $\$ 100,000$ per space in reduced revenue to the park. ${ }^{197}$

When the regulatory takings claim reached the Ninth Circuit, the panel opinion by Judge Bybee could serve as a primer on the application of Penn Central as a three-factor balancing test. ${ }^{198}$ Looking first at the economic impact of the regulation, the court cited evidence that the rent ordinance depressed park revenues to nearly $80 \%$ below the market. ${ }^{199}$ The character of the government action consisted of a one-time wealth transfer from the park owners to the tenants in occupancy at the time the ordinance was adopted. ${ }^{200}$ As such, Goleta's rent control law was a classic example of a regulation that effected "the distribution of resources or opportunities to one group rather than another solely on the ground that those favored have exercised the raw political power to obtain what they want."201 Finally,

194. See Guggenheim I, 582 F.3d at 1021; Guggenheim II, 638 F.3d at 1136 (Bea, J., dissenting).

195. See, e.g., Diehang Zheng ET AL., An examination of the impact of rent control on mobile home prices in California, 16 J. HousING ECON. 209 (2007); Carl Mason \& John Quigley, The Curious Institution of Mobile Home Rent Control: An Analysis of Mobile Home Parks in California (U. C. Berkeley Program on Housing and Urban Policy, June 1, 2006); David Dale-Johnson ET AL., An Examination of the Impact of Rent Control on Mobile Home Prices in California, Working Paper No. 2004-1010, Lusk Center for Real Estate, University of Southern California (Sept. 2006); Werner Z. Hirsch \& Anthony M. Rufolo, The Regulation of Immobile Housing Assets Under Divided Ownership, 19 INT'L REV. L. \& ECON. 383 (1999); Werner Z. Hirsch \& Joel G. Hirsch, Legal-Economic Analysis of Rent Controls in a Mobile Home Context: Placement Values and Vacancy Decontrol, 35 UCLA L. REV. 399 (1988); Werner Z. Hirsch, An Inquiry into Effects of Mobile Home Park Rent Control, 24 J. URB. ECON. 212 (1988).

196. Guggenheim II, 638 F.3d at 1134.

197. Guggenheim I, 582 F.3d at 1023.

198. See Pomeroy, supra note 175, at 700-02.

199. Guggenheim I, 582 F.3d at 1020.

200. Id. at 1021 .

201. Id. (quoting Cass R. Sunstein, Naked Preferences and the Constitution, 84 
Judge Bybee noted that the existence of the county's rent ordinance prior to the Guggenheims' purchase of the park minimized any purported interference with their investment-backed expectations. ${ }^{202}$ Still, Palazzolo established that mere preexistence of a regulatory scheme cannot, without more, foreclose a successful challenge to those regulations under the Takings Clause. ${ }^{203}$ In this case, because the economic impact and character of the regulations weighed heavily in the plaintiffs' favor, the Guggenheims established that the rent ordinance effected a compensable taking under Penn Central. In a passage reminiscent of Justice Holmes's opinion in Pennsylvania Coal v. Mahon, ${ }^{204}$ the Guggenheim majority concluded:

If the City of Goleta wishes to attempt to increase the availability of affordable housing by transferring the value of renting land within its jurisdiction from the Park Owners to the incumbent tenants, there is no constitutional impediment to doing so. The Fifth Amendment of the U.S. Constitution, however, requires that the City compensate the Park Owners for taking their property by regulation. ${ }^{205}$

But that victory was short-lived. Granting the City's request for rehearing en banc, the Ninth Circuit in 2010 handed down a new opinion rescinding and reversing the panel's holding. ${ }^{206}$ In place of Judge Bybee's careful weighing of the three independent Penn Central factors, the en banc opinion by Judge Kleinfeld collapsed the entire analysis into a single "primary" consideration that he found "fatal to the Guggenheims' claim" - that the park was subject to the county rent control ordinance before the Guggenheims acquired title. ${ }^{207}$ Holding that the pre-acquisition existence of regulation - even a different regulation - completely destroys any possible expectation that an unconstitutional enactment might be overturned, the en banc

COLUM. L. ReV. 1689, 1689 (1984)).

202. Id. at $1023-24$.

203. Id. at 1005 (citing Palazzolo v. Rhode Island, 533 U.S. 606, 630 (2001)).

204. See Pennsylvania Coal v. Mahon, 260 U.S. 393, 416 (1922) ("We are in danger of forgetting that a strong public desire to improve the public condition is not enough to warrant achieving the desire by a shorter cut than the constitutional way of paying for the change.")

205. Guggenheim I, 582 F.3d at 1030.

206. Guggenheim II, 638 F.3d 1111, 1137 (9th Cir. 2010).

207. Id. at 1120 . 
opinion in every respect embraced the Rhode Island Supreme Court's reasoning in Palazzolo, which was forcefully repudiated by the Supreme Court a decade earlier. ${ }^{208}$ Indeed, the Ninth Circuit went further, suggesting that the Guggenheims' tenants had distinct, investment-backed expectations amounting to a constitutionally protected property interest in the indefinite continuation of restrictive rent control. ${ }^{209}$ This novel interpretation of Penn Central's expectations prong runs directly contrary to Justice Scalia's observation in Palazzolo - that legally cognizable expectations "do not include the assumed validity of a restriction that in fact deprives property of so much of its value as to be unconstitutional." 210

By adopting the discredited Notice Rule as the law in Guggenheim, the Ninth Circuit carved out a potentially vast swath of land use regulations that, although they might have been flagrantly unconstitutional when they were enacted, become immune to takings challenges on a parcel-by-parcel basis as regulated property changes hands. This is the process Justice Kennedy refers to in Palazzolo as "put[ting] an expiration date on the Takings Clause." 211 Such is the force of the doctrine that, despite Penn Central's insistence that takings liability depends upon "ad hoc, factual inquiries" into the particular circumstances of each case, ${ }^{212}$ those facts become irrelevant in cases involving pre-acquisition regulations. An extreme illustration is MHC Financing Limited Partnership v. City of San Rafael - another challenge to mobile home park rent control in which the district court found a regulatory taking based on a detailed factual record compiled over eight years of litigation. ${ }^{213}$ Before reversing under the Notice

208. See Palazzolo v. Rhode Island, 746 A.2d 707, 715-17 (R.I. 2000). The Guggenheim en banc opinion effectively limited the Supreme Court's ruling to its facts, finding it dispositive that title to Palazzolo's land passed by operation of law, from corporate to individual ownership, while Palazzolo was applying for permits facts that played no role whatsoever in the Supreme Court's holding. Guggenheim II, 638 F.3d at 1118.

209. Guggenheim II, 638 F.3d at 1122.

210. Palazzolo v. Rhode Island, 533 U.S. 606, 637 (2001) (Scalia, J., concurring). 211. Id. at 627 . By suggesting that federal courts should afford constitutional protection to "investments" in legislative wealth transfers, Judge Kleinfeld's Guggenheim opinion undermines the role of the judiciary in maintaining a stable system of private property rights. See J. David Breemer \& R. S. Radford, The (Less?) Murky Doctrine of Investment-Backed Expectations after Palazzolo, and the Lower Courts' Disturbing Insistence on Wallowing in the Pre-Palazzolo Muck, 34 Sw. U. L. REV. 351, 417-25 (2005) (providing an elaboration of how rulings of this kind promote the phenomenon Bryan Caplan has dubbed "rational irrationality").

212. Penn Cent. Transp. Co. v. New York City, 438 U.S. 104, 124 (1978).

213. 714 F.3d 1118, 1123-24 (9th Cir. 2013). 
Rule on appeal, the Ninth Circuit joked that "it [is] déjà vu all over again." 214 As in Guggenheim, the MHC Financing court found that the existence of (substantially different) rent regulations prior to the plaintiff's acquisition of the park not only eliminated any reasonable expectation that the ordinance could be found unconstitutional but also resolved the other two Penn Central factors in favor of the government. ${ }^{215}$

The misapplication of Penn Central's investment-backed expectations inquiry under the Notice Rule - in direct contravention of Palazzolo - has not been confined to the Ninth Circuit; although Guggenheim is the only instance in which that doctrine has been elevated to the law of the circuit by an en banc panel. ${ }^{216}$ With the demise of Williamson County, however, the attraction of this option as a way to clear takings cases from federal court dockets may prove even more compelling.

\section{Epilogue: The Ninth Circuit Becomes Both Judge and Jury in Takings Cases}

Ten years after Guggenheim, and after this Article had been submitted for publication, a Ninth Circuit panel reversed a jury verdict awarding damages for a temporary regulatory taking in Bridge Aina Le'a v. State of Hawaii Land-Use Commission. ${ }^{217}$ The property at issue consisted of 1,060 acres of barren land covered with rough, rocky lava flow. ${ }^{218}$ The Hawaii Land-Use Commission ("LUC") zoned the property for agricultural use until 1989 when it was upgraded to "urban usage" at the owner's request to allow for development. ${ }^{219}$ The land's current owner, Bridge Aina Le'a ("Bridge"), invested \$20 million in the project when the LUC (illegally, as was later determined) "reverted" the property's zoning to agricultural use-for

214. Id. at 1122

215. Id. at $1127-28$.

216. See, e.g., CRV Enters. v. United States, 656 F. 3d 1241, 1248-50 (Fed. Cir. 2010) (subsequent purchaser lacks standing to challenge implementation of previously-enacted measure restricting access to property); D.A.B.E., Inc., v. City of Toledo, 292 F. Supp. 2d 968, 972 (N.D. Ohio 2003), aff'd on other grounds, 393 F.3d 692 (2005) (holding that businesses challenging smoking ban lacked reasonable expectations because they had "long been on notice that the value of their investments, and implicitly, the ability to profit from such businesses, may be affected adversely by continuing governmental efforts to reduce exposure to secondhand smoke.").

217. 950 F.3d 610, 610-11 (9th Cir. 2020).

218. Id. at $617-18$.

219. Id. at 618-19. 
all practical purposes - the equivalent of designating the site for open space. ${ }^{220}$ This eliminated the land's value for development, and caused a pending $\$ 40.7$ million sale of part of the project to fall through. ${ }^{221}$

Some five years after LUC designated the property for agricultural use, Bridge prevailed when the Hawaii Supreme Court invalidated the order of reversion. ${ }^{222}$ Subsequently, in an action removed to federal court by the State, Bridge sued for a temporary taking, alleging LUC's actions gave rise to liability for compensation under both Penn Central and Lucas. ${ }^{223}$ After an eight-day jury trial, the district court agreed. The jury found that the property was deprived of all economically viable use for the time the agricultural zoning was in place, thus meeting the Supreme Court's standard for a Lucas taking. Turning to the Penn Central factors, the fact that LUC's reversion order was unlawful and may have been intended to "force Bridge to sell the [p]roperty to another owner/developer" tipped the character of the government action in favor of a taking. ${ }^{224}$ The jury determined that the economic impact of the reversion was significant based on expert testimony that the property lost $83.5 \%$ of its market value when it was designated for agricultural use. ${ }^{225}$ Finally, evidence considered by the jury indicated that Bridge had a reasonable, investment-backed expectation of selling the property for $\$ 40$ million under the urban zoning category, but those expectations were shattered when the LUC's illegal reversion dropped the value of the parcel to $\$ 6.6$ million, causing the sale to fall through. ${ }^{226}$

Denying the Commission's post-trial motion for judgment as a matter of law, the trial judge reviewed all elements of the jury's finding and found them to be reasonable in light of the jury instructions that both sides agreed upon and supported by credible evidence in the record. ${ }^{227}$ The Ninth Circuit reversed on appeal, holding that "no reasonable jury" could find a taking on these facts. ${ }^{228}$ In so doing, the appellate panel extensively reweighed and reevaluated

220. Id. at 622; DW Aina Le'a Dev., LLC v. Bridge Aina Le'a, LLC, 339 P.3d 685, 712 (Haw. 2014).

221. Bridge Aina Le'a, 950 F.3d at 620-21, 633 .

222. See DW Aina Le'a Dev., 339 P.3d 685-86.

223. Bridge Aina Le'a, 950 F.3d at 623-24.

224. See Order Den. Haw.'s Renewed Mot. J. as a Matter of L. or, New Trial at 66; Bridge Aina Le'a v. Haw. Land-Use Comm'n, 950 F.3D 610 (2020) (No. 1:11cv-00414-SOM-KJM), 2018 WL 3149489, at*24.

225. See generally Order, supra note 225 at 56.

226. Id. at $63-64$.

227. See generally id at 66 .

228. Bridge Aina Le'a, $L L C, 950$ F.3d at 637. 
the evidence before the trial court, going so far as to substitute its own opinion of the credibility of witnesses for the jury's evaluation. ${ }^{229}$

The tone of the appellate opinion is exemplified by the panel's finding that Bridge's property was not in fact deprived of all economically viable use, as the jury had determined, in part because one expert sarcastically commented that the lava-covered parcel could still be used for "growing rocks." 230 As to the Penn Central factors, the court disputed the expert testimony that was presented to the jury, relying instead upon its own speculations as to when the economic impact of the reversion began and ended. ${ }^{231}$ Under this evaluation of the evidence, as opposed to the jury's, the economic impact of the reversion was limited to a single year instead of five, thereby reducing the diminution in the property's value to $\$ 6.72$ million. $^{232}$

Concerning the effect of the reversion on Bridge's investmentbacked expectations, the Ninth Circuit invoked an even more amorphous version of the long-discredited Notice Rule than the one resurrected in Guggenheim. ${ }^{233}$ Here, it was undisputed that Bridge owned the property at the time the Commission downzoned it to agricultural use. But the Ninth Circuit looked to the "regulatory environment" at the time Bridge acquired the parcel, citing prePalazzolo caselaw for the proposition that "those who do business in the regulated field cannot object" when subsequent regulations destroy the economic viability of their property. ${ }^{234}$ Bridge's \$20 million

229. See, e.g., id. at 631 (complaining that the parties - and, by implication, the jury - "agree, uncritically" on the meaning of an expert witness's testimony at trial, whereupon the appellate panel substitutes its own analysis of the facts for the expert's).

230. Id. at 630 .

231. Id. at 631-33. This was reminiscent of the economic speculations of the Guggenheim en banc panel, which simply proclaimed that the purchase price of the plaintiffs" mobile home park "doubtless" fully discounted the expectation of perpetual rent control - an important question of fact essential to the panel's reasoning, but for which the record contained no evidence whatsoever. Guggenheim II, 638 F.3d 1111, 1120 (9th Cir. 2010).

232. Bridge Aina Le'a, $L L C, 950$ F.3d at 632.

233. See supra text accompanying notes 208-10.

234. Bridge Aina Le'a, LLC, 950 F.3d at 634 (citing Concrete Pipe \& Prods. v. Constr. Laborers Pension Tr., 508 U.S. 602, 645 (quoting FHA v. The Darlington, Inc., 358 U.S. 84, 91 (1958))). For other pre-Palazzolo applications of this “anticipatory taking” doctrine, see Dist. Intown Props., Ltd. P'Ship v. Dist. of Columbia, 198 F.3d 874, 883 (D.C. Cir. 1999) (holding that the plaintiffs "could have reasonably expected" that they would not be able to develop their commercial real estate, given the existence of a law authorizing the Fine Arts Commission to make recommendations about actions affecting the public values of the National Zoo); Good v. United States, 189 F.3d 1355, 1363 (Fed. Cir. 1999) ("In light of the 
investment in developing the property was dismissed as irrelevant; "we do not see," as the court put it, "what this proves." 235 Because the Commission had the statutory authority to revert the land's designation to agricultural in mid-development, even if it did so illegally, "this factor weighs strongly against finding a taking."236

The appellate panel grudgingly conceded that the illegality of the Commission's action, and its apparent motivation of forcing Bridge to dispose of the property, might conceivably be interpreted as weighing in favor of takings liability under Penn Central's "character" prong. 237 But under the panel's reevaluation and reweighing of the evidence, the reversion's economic impact on Bridge's investment-backed expectations were found to "weigh decisively against such a finding," 238 and "no reasonable jury" could have come to any other conclusion. ${ }^{239}$

The Supreme Court has repeatedly admonished that takings liability depends on a case-by-case, ad-hoc, fact-intensive inquiry ${ }^{240}$ - a function that is traditionally entrusted to juries. ${ }^{241}$ Indeed, the Court has specifically held that whether the facts of a given case meet the Penn Central standards is a question that should be determined by a jury. ${ }^{242}$ Nevertheless, this was not the first time the Ninth Circuit set aside a jury's verdict of takings liability by reevaluating the evidence considered at trial and substituting its own factual determinations. ${ }^{243}$

growing consciousness of and sensitivity toward environmental issues, [the landowner] must also have been aware that standards could change to his detriment").

235. Bridge Aina Le'a, $L L C, 950$ F.3d at 635.

236. Id.

237. Id. at 635-37.

238. Id. at 637 .

239. Id.

240. See, e.g., Penn Central Trans. Co. v. City of New York, 438 U.S. 104, 124 (1978); Palazzolo v. Rhode Island, 533 U.S. 606, 633 (2001).

241. "The function of jury is to determine the facts based solely on a fair consideration of the evidence. The jury determines what evidence to accept, how important any evidence is and what conclusions to draw from all the evidence," USLEGAL, https://courts.uslegal.com/jury-system/the-function-of-the-jury-at-thetrial/ [https://perma.cc/8A56-HHZA]; see also United States v. Gaudin, 515 U.S. 506,512 (1995) ("the application of legal standard-to-fact sort of question[s] ha[ve] typically been resolved by juries"); TSC Indus., Inc. v. Northway, Inc., 426 U.S. 438, 450 (1976) (recognizing that a jury is well suited to weigh the "delicate assessments of the inferences a 'reasonable [decisionmaker]' would draw from a given set of facts").

242. See City of Monterey v. Del Monte Dunes, 526 U.S. 687, 720-21 (determination of loss of economically viable use "is for the jury" to decide.).

243. See Colony Cove Props. v. City of Carson, 888 F.3d 445, 449, n.3, 455 (9th Cir. 2018) (Although both the jury and the trial judge independently weighed the 
This raises a serious question of whether the Ninth Circuit in these cases is flouting the Seventh Amendment's Reexamination Clause: "[N]o fact tried by a jury, shall be otherwise re-examined in any Court of the United States, than according to the rules of the common law." 244 As Professor Tribe noted, the Reexamination Clause "was adopted principally to protect jury verdicts from after-the-fact judicial interference, especially by appellate courts." ${ }^{245}$ Yet this after-the-fact questioning of jury findings forms the core of the Ninth Circuit's opinion in Bridge Aina Le'a. Bridge's petition for certiorari to the Supreme Court raised this point, but the prospects of granting review on that basis seem slight. ${ }^{246}$

\section{CONCLUSION: A NEW DAY OR ... ?}

Senator Whitehouse's anti-Knick diatribe saw the decision as signaling a "new day" in which federal judges would impose financial liability on local governments under the Takings Clause with gay abandon. ${ }^{247}$ This vision comports with a widely shared perception that federal judges - whose opportunity to adjudicate takings claims was severely limited by Williamson County-will be inherently more inclined to uphold property owners' constitutional rights than their colleagues in the state judiciary. However, as this Article has shown there is little empirical support for this belief.

The hostility of state judges to takings claims against local governments may be, as has been widely assumed, a function of the local political process of which they are inherently involved. But this does not necessarily imply that eliminating those pressures will eliminate the hostility. This Article demonstrated that federal courts have their own incentives for discouraging litigants from pursuing claims for Takings Clause violations. In particular, the often-voiced distaste of federal judges for adjudicating local land use disputes may manifest itself in the observed tendency to rule in favor of government defendants if they can prevail on any one of Penn Central's three

evidence and found the facts supported a finding of takings liability, the Ninth Circuit reevaluated the same evidence, substituting its own opinions of credibility for those of the trial court, and concluded that "no reasonable finder of fact" could have found a taking had occurred.).

244. U.S. CONST. amend. VII.

245. Laurence Tribe, American Constitutional Law 624 (3d ed., 2000).

246. See Pet. for Writ of Cert. at 31 , Bridge Aina Le'a, LLC v. Hawaii Land-Use Comm'n, (No. 20-54) (2020).

247. See Whitehouse, supra note 96. 
elements for establishing takings liability. ${ }^{248}$ As Robert Thomas has observed:

Knick's critical recognition that the federal courts should be open to protect the federal constitutional rights of property owners will have little impact if all it means is that owners can now go to federal court and invariably lose, simply because the prevailing standard is so open to interpretation that it can support any reason to deny a claim. ${ }^{249}$

Or, as another leading land-use practitioner put it, "Knick may only mean that takings plaintiffs will be able to lose their cases more quickly." 250

In effect, Knick returned federal takings jurisprudence to where it stood in 1984, before Williamson County's ill-conceived shunting of most cases to state court. How the law develops from here, and what sort of regulatory takings doctrine is developed by judges holding life tenure, free of local political pressure, remains to be seen.

248. See supra, notes 118-29, 179.

249. Robert H. Thomas, Here Be Dragons: New Amicus Brief Asks For A "Fresh Look" At The Penn Central Test, INVERSECONDEMnATION.COM (Sep. 17, 2019), https://www.inversecondemnation.com/inversecondemnation/2019/09/here-bedragons-new-amicus-brief-asks-for-a-fresh-look-at-the-penn-central-test.html [https://perma.cc/DG7P-J8C7].

250. Merriam, supra note 164, at 650 . 